\title{
Isotopic, geophysical and biogeochemical investigation of submarine groundwater discharge: IAEA-UNESCO intercomparison exercise at Mauritius Island
}

\author{
P.P. Povinec ${ }^{\mathrm{a},{ }^{*}}$, W.C. Burnett ${ }^{\mathrm{b}}$, A. Beck ${ }^{\mathrm{c}}$, H. Bokuniewicz ${ }^{\mathrm{c}}$, M. Charette ${ }^{\mathrm{d}}$, M.E. Gonneea ${ }^{\mathrm{d}}$, M. \\ Groening $^{\mathrm{e}}$, T. Ishitobi ${ }^{\mathrm{f}}$, E. Kontar ${ }^{\mathrm{g}, \#}$, L. Liong Wee Kwong ${ }^{\mathrm{h}}$, D.E.P. Marie ${ }^{\mathrm{i}}$, W.S. Moore, J.A.



\author{
${ }^{a}$ Comenius University, Faculty of Mathematics, Physics and Informatics, 84248 Bratislava, Slovakia \\ ${ }^{b}$ Florida State University, Department of Oceanography, Tallahassee, FL 32306, USA \\ ${ }^{c}$ Stony Brook University, Marine Sciences Research Center, Stony Brook, NY 11794-5000, USA \\ ${ }^{d}$ Woods Hole Oceanographic Institution, Department of Marine Chemistry and Geochemistry, Woods Hole, MA 02543, USA \\ ${ }^{e}$ International Atomic Energy Agency, Isotope Hydrology Section, Vienna, Austria \\ ${ }^{f}$ Research Institute for Humanity and Nature, Kyoto, Japan \\ ${ }^{g}$ Shirshov Institute of Oceanology, Moscow, Russian Federation \\ ${ }^{h}$ International Atomic Energy Agency, Marine Environmental Laboratories, MC 98000, Monaco \\ ${ }^{i}$ Mauritius Oceanography Institute, Quatre Borne, Mauritius \\ ${ }^{j}$ University of South Carolina, Department of Geological Sciences, Columbia, SC 20208, USA \\ ${ }^{k}$ San Jose State University, Department of Geology, San Jose, CA 95192-0102, USA \\ ${ }^{l}$ University of Mauritius, Department of Chemistry, Reduit, Mauritius \\ ${ }^{m}$ James Cook University, School of Engineering \& Physical Sciences, Townsville, Australia, and Australian Institute of Marine Sciences, Townsville, \\ Australia \\ ${ }^{n}$ University of Miami, Rosenstiel School of Marine and Atmospheric Science, Miami, Florida, USA
}

\begin{abstract}
Submarine groundwater discharge (SGD) into a shallow lagoon on the west coast of Mauritius Island (Flic-en-Flac) was investigated using radioactive $\left({ }^{3} \mathrm{H},{ }^{222} \mathrm{Rn},{ }^{223} \mathrm{Ra},{ }^{224} \mathrm{Ra},{ }^{226} \mathrm{Ra},{ }^{228} \mathrm{Ra}\right)$ and stable $\left({ }^{2} \mathrm{H},{ }^{18} \mathrm{O}\right)$ isotopes and nutrients. SGD intercomparison exercises were carried out to validate the various approaches used to measure SGD including radium and radon measurements, seepage-rate measurements using manual and automated meters, sediment bulk conductivity and salinity surveys. SGD measurements using benthic chambers placed on the floor of the Flic-en-Flac Lagoon showed discharge rates up to 500 $\mathrm{cm} /$ day. Large variability in SGD was observed over distances of a few meters, which were attributed to different geomorphological features. Deployments of automated seepage meters captured the spatial and temporal variability of SGD with a mean seepage rate of $10 \mathrm{~cm} /$ day. The stable isotopic composition of submarine waters was characterized by significant variability and heavy isotope enrichment and was used to predict the contribution of fresh terrestrially derived groundwater to SGD (range from a few \% to almost $100 \%$ ). The integrated SGD flux, estimated from seepage meters placed parallel to the shoreline, was $35 \mathrm{~m}^{3} / \mathrm{m}$ day, which was in a reasonable agreement with results obtained from hydrologic water balance calculation $\left(26 \mathrm{~m}^{3} / \mathrm{m}\right.$ day). SGD calculated from the radon inventory method using in situ radon measurements were between 5 and $56 \mathrm{~m}^{3} / \mathrm{m}$ per day. Low concentrations of radium isotopes observed in the lagoon water reflected the low abundance of $U$ and Th in the basalt that makes up the island. High SGD rates contribute to high nutrients loading to the lagoon, potentially leading to eutrophication. Each of the applied methods yielded unique information about the character and magnitude of SGD. The results of the intercomparison studies have resulted a better understanding of groundwater-seawater interactions in coastal regions. Such information is an important pre-requisite for the protection management of coastal freshwater resources.
\end{abstract}

Keywords: Submarine groundwater discharge; Groundwater; Seawater; Seepage meters; Stable isotopes; $\delta \mathrm{D} ; \delta^{18} \mathrm{O}$; Tritium; Radium isotopes, Radon; Nutrients; Coastal zone; Volcanic island; Mauritius Island

\footnotetext{
${ }^{*}$ Corresponding author. Formerly at the International Atomic Energy Agency, Marine Environment Laboratories, Monaco. Present address: Comenius University, Faculty of Mathematics, Physics and Informatics, Mlynska dolina F-1, SK-84248 Bratislava, Slovakia; Phone: +421 260295544 ; Fax: +421 265425 882; E-mail address: povinec@,fmph.uniba.sk

${ }^{\#}$ Present address: Illinois State Geological Survey, 615 E. Peabody Drive, Champaign, Illinois 61820-6964, USA.
} 


\section{Introduction}

Radioactive and stable isotopes have proven to be useful tracers of submarine groundwater discharge (SGD), which can occur both as channeled flow (i.e. springs) or dispersed seepage. Since these isotope tracers integrate SGD fluxes over the scale of sampling, they have contributed to a better understanding of SGD dynamics, opposed to physical seepage measurements, which only constrain SGD fluxes on small, local scales (Burnett et al., 2006; Moore, 2006; Povinec et al., 2006a,b, 2008a,b,c; Swarzenski et al., 2006; Cable et al., 2004; Weinstein et al., 2006; Stieglitz et al., 2008).

Stable deuterium $\left({ }^{2} \mathrm{H}\right)$, oxygen isotopes $\left({ }^{16} \mathrm{O},{ }^{18} \mathrm{O}\right)$, and radioactive tritium $\left({ }^{3} \mathrm{H}\right)$ have been used as conservative tracers of mixing processes at the groundwater-seawater interface, since seawater and meteoric groundwater have unique end-member signatures (Povinec et al., 2008a,b; Schiavo et al., 2007, 2009). Tritium present in the environment is mostly of global fallout origin (Livingston and Povinec, 2002), and due to its peak input to the atmosphere (1963) and suitable half-life (12.32 y) is frequently used for dating of groundwater (Povinec et al., 2008c). Radium has four isotopes of varying half-lives $\left({ }^{223} \mathrm{Ra}, \mathrm{t}_{1 / 2}=11.4 \mathrm{~d} ;{ }^{224} \mathrm{Ra}, \mathrm{t}_{1 / 2}=3.66 \mathrm{~d} ;{ }^{226} \mathrm{Ra}, \mathrm{t}_{1 / 2}=1600 \mathrm{y}\right.$ and $\left.{ }^{228} \mathrm{Ra}, \mathrm{t}_{1 / 2}=5.75 \mathrm{y}\right)$ and is ideally suited to estimate water exchange rates in coastal zones, as well as to assess coastal integrated SGD fluxes (Moore, 1996, 2000, 2006; Moore and Wilson, 2005). Radon $\left({ }^{222} \mathrm{Rn}\right)$ is a conservative tracer, suitable for studying the dynamics of groundwater-seawater interactions. Its short half-life $(3.83 \mathrm{~d})$ and large enrichment in groundwater relative to seawater make it an ideal groundwater tracer across the temporal and spatial scales relevant to SGD in coastal zones (Burnett and Dulaiova, 2003, 2006; Burnett et al. 2006; Povinec et al., 2006a,b, 2008a,b). One advantage of ${ }^{222} \mathrm{Rn}$ as a groundwater tracer is that spatial mapping and time series measurements are possible with available in situ technologies, based either on alpha-spectrometry (Burnett et al., 2001; Burnett and Dulaiova, 2003, 2006; Stieglitz et al 2010) or gamma-spectrometry (Povinec et al., 1996, 2001; Osvath and Povinec, 2001). Using this technique, the change in radon inventories over time can be modeled to estimate groundwater discharge.

Combining these techniques with physical measurements (i.e. temperature, conductivity, geoelectric probing, and benthic flux chambers) provides a powerful tool to quantify and characterize SGD in the coastal zone (Burnett et al., 2006). The International Atomic Energy Agency (IAEA) in cooperation with the United Nations Educational, Scientific and Cultural Organization (UNESCO) carried out series of SGD investigations, some of them in the framework of the IAEA Coordinated Research Project (CRP) "Nuclear and Isotopic Techniques for the Characterization of Submarine Groundwater Discharge in Coastal Zones". The objectives of the CRP included the development of radioactive as well as nonradioactive tracer techniques. Several intercomparison experiments were carried out in different 
hydrogeologic environments including: coastal plain (Australia, 2000; Burnett et al., 2006); karst (Sicily, 2002; Burnett et al., 2006; Povinec et al. 2006a,b); glaciofluvial deposits (Long Island, 2002; Burnett et al., 2006); fractured crystalline rocks (Brazil, 2003; Burnett et al., 2006; Povinec et al., 2008a,b); and volcanic island (Mauritius, 2005, this study).

This paper summarizes the results obtained during the SGD intercomparison experiment carried out during March (18-25) 2005 along the west coast of Mauritius (Burnett et al., 2005). The following methods were used during the field study by the UNESCO-IAEA experts and colleagues from the University of Mauritius, the Mauritius Oceanography Institute, and the Water Resources Unit:

(i) In situ water column salinity/temperature (CTD) mapping and ground conductivity (within beach sediments) surveys along the coast;

(ii) Seawater sampling in the lagoon and open ocean for radioactive $\left({ }^{3} \mathrm{H}, \mathrm{Ra}\right.$ isotopes) and stable $\left({ }^{2} \mathrm{H},{ }^{18} \mathrm{O}\right)$ isotopes, and nutrients;

(iii) In situ spatial mapping and time series measurements of ${ }^{222} \mathrm{Rn}$ in coastal waters;

(iv) Deployment of manual and automated seepage chambers, including water sampling from seepage chambers for analysis of radioactive $\left({ }^{3} \mathrm{H}\right)$ and stable $\left({ }^{2} \mathrm{H},{ }^{18} \mathrm{O}\right)$ isotopes and nutrients;

(v) Collection of groundwater data from temporary wells drilled into the beach (radioactive $\left({ }^{3} \mathrm{H}\right.$, ${ }^{222} \mathrm{Rn}$, Ra isotopes) and stable $\left({ }^{2} \mathrm{H},{ }^{18} \mathrm{O}\right)$ isotopes, and nutrients);

(vi) Collection of groundwater data from wells and surface springs (radioactive $\left({ }^{3} \mathrm{H}\right.$, Ra isotopes) and stable $\left({ }^{2} \mathrm{H},{ }^{18} \mathrm{O}\right)$ isotopes, and nutrients).

This work is a continuation in the series of papers on the development of nuclear and isotopic technologies for SGD quantification carried out in the framework of the IAEA-UNESCO SGD cooperation (Povinec et al., 2006a; 2008a). It represents the most comprehensive study carried out till now on the characterization of SGD using isotopic, geophysical, geobiochemical and hydrological methods.

\section{Study site}

Mauritius, is a volcanic island (7.8 My old, $1865 \mathrm{~km}^{2}$ ) located in the central western Indian Ocean $\left(\sim 20^{\circ} \mathrm{S}, 57^{\circ} \mathrm{E}\right)$. Previous studies have shown that volcanic islands are potentially important sources of SGD (Garrison et al., 2003; Kim et al., 2003). This site was chosen for the SGD intercalibration study because the volcanic ocean island geological environment was missing in the previous IAEA-UNESCO SGD studies. Much of the rainfall occurs during the summer cyclonic season (December to April, 900 to $4000 \mathrm{~mm} / \mathrm{y}$, 
depending on elevation), and is associated with discrete events with significant year-to-year variability (Proag, 1995).

Mauritius Island has a maximum elevation of $800 \mathrm{~m}$ and has a high central plateau that slopes down to the coast (Fig. 1). The coastal zone is largely comprised of lagoons, covering an area of $\sim 240 \mathrm{~km}^{2}$. These lagoons are wide and shallow (500 $\mathrm{m}$ at Flic en Flac, $\sim 1 \mathrm{~m}$ water depth), with a barrier coral reef. Previous studies have reported substantial groundwater discharge to the lagoons from the volcanic aquifers (Paytan et al. 2006). In addition, the lagoons experience enhanced nutrient loading and eutrophication that is of concern to the coral reef ecosystems of Mauritius (Ramessur, 2002; Turner et al., 2000). In addition, coprostanol, a component of feces, has been detected in high quantities along the east and west coasts of Mauritius, suggesting input of inland sewage pollution (Gendre et al., 1994).

The main field study was carried out on Mauritius Island during March 18-25, 2005, following a preliminary small-scale sampling in April 2004 on the western coast of the island near the town of Flicen-Flac (Fig. 1). The study site is sheltered from the dominant southeastern winds, however during the later part of the field study, tropical cyclone Hennie passed $150 \mathrm{~km}$ offshore of west coast of the island, generating winds up to $18 \mathrm{~m} / \mathrm{s}$ and moderate $2 \mathrm{~m}$ swells.

The main inland water body is the Curipipe Aquifer $\left(\sim 95 \mathrm{~km}^{2}\right)$ which extends $15 \mathrm{~km}$ from the high central plateau to the west coast (Giorgi et al., 1999). It consists of highly permeable, Younger Series lava flows (1.5 My to $25 \mathrm{ky}$ ) with a saturated thickness of 10 to $20 \mathrm{~m}$, and a range of transmissivity of $10^{-5}$ to $10^{-2} \mathrm{~m}^{2} / \mathrm{s}$ (Giorgi et al., 1999). In addition, formation of lava flows contains a number of lava tubes that are thought to be highly transmissive ( $\mathrm{T}>10^{-1} \mathrm{~m}^{2} / \mathrm{s}$; MPW, 2003), providing preferential groundwater flow paths. Underlying these flows is a clayey, weathered horizon, 5 to $10 \mathrm{~m}$ thick, which acts as an aquitard (Giorgi et al., 1999). This clayey aquitard is the weathered top of the Intermediate Series lava flows (3.5 to $1.9 \mathrm{My}$ ) that are approximately $100 \mathrm{~m}$ thick and less permeable. The transmissivity of these flows ranges from $10^{-6}$ to $10^{-3} \mathrm{~m}^{2} / \mathrm{s}$ (MPW, 2003). Underlying these flows are Older Series basaltic flows (5.5 to 7.8 My) that are considered impermeable (McDougal and Chamalaun 1969; Giorgi et al., 1999).

Mauritius relies heavily upon groundwater to meet both potable water demand (about $56 \%$ of that demand is satisfied by groundwater) and agricultural demand, primarily for the water-thirsty, sugar-cane industry. Because of this, a network of monitoring wells, stream gauging stations, and meteorological stations has been established on the island to collect a variety of data related to both groundwater and surface water (MPW, 2003).

\section{Methods}

\subsection{Field measurements}




\subsection{1. ${ }^{222}$ Rn measurements}

A combination of ${ }^{222} \mathrm{Rn}$ mapping surveys and time-series measurements were used to quantify SGD fluxes during the intercomparison experiment. An automated radon monitor (Burnett et al., 2001; Burnett and Dulaiova, 3003, 2006) was used for continuous measurement of ${ }^{222} \mathrm{Rn}$ in coastal waters. ${ }^{222} \mathrm{Rn}$ mapping was accomplished by integrating several radon detectors with GPS navigation, water depth and temperature/conductivity measurements (Dulaiova et al., 2005). A constant stream of water is delivered by a submersible pump to an air-water exchanger where radon in the water phase equilibrates with radon in a closed air loop. The air stream is fed to a radon-in-air monitor to determine the activity of ${ }^{222} \mathrm{Rn}$. Continuous measurements of air temperature, wind speed/direction, rainfall, barometric pressure and sea level were also made.

\subsubsection{Salinity and temperature measurements}

Seawater salinity and temperature in the lagoon and open sea were continuously measured in situ using a CTD (NXIC, Falmouth Scientific). Measurement precision was $\pm 0.002 \mathrm{mS} / \mathrm{cm}$ for conductivity, $\pm 0.002{ }^{\circ} \mathrm{C}$ for temperature and $\pm 0.002 \%$ for pressure. Near-shore salinity surveys in the northern portion of Flic-en-Flac Lagoon were carried out with a water quality sensor (Hydrolab MiniSonde-4a), which was towed just under the water surface approximately $5 \mathrm{~m}$ from the shore. The sensor was setup to record data in $30 \mathrm{~s}$ intervals, and was towed at a speed of $\sim 2.0 \mathrm{~km} / \mathrm{h}$, resulting in a spatial resolution of $15-20 \mathrm{~m}$. The position was continuously recorded with a handheld Garmin GPS. Groundwater samples collected from onshore wells were analyzed using a conductivity meter (LF 323/SET, WRW). The precision of conductivity and temperature measurements was $\pm 0.5 \%$ and the precision of salinity measurements was \pm 0.1 . All sensors were calibrated according to factory-specified procedures, and a seawater standard (Oceanor Scientific Instruments Atlantic Sea Water 35) was used for inter-instrument conductivity/salinity calibrations.

\subsubsection{Ground conductivity measurements}

Ground conductivity surveys were carried out at selected sites to identify discharge locations at a higher spatial resolution (meter-scale) using a high-resolution conductivity probe described in Stieglitz et al. (2000). The bulk ground conductivity is a function of (conducting) salt present in the ground, which depends on pore water fraction and on pore water conductivity, which in turn is a function of pore water salinity and temperature. Vertical conductivity profiles were recorded by inserting the probe into the ground, taking a reading at a particular depth, and then gradually pushing the probe further into the ground. Along a profile, readings were taken every $5-10 \mathrm{~cm}$. A transect consisted of a number of vertical profiles taken at a spacing of 1 to $5 \mathrm{~m}$. Transect data was interpolated by kriging using Surfer 6.0, taking 
into account a spatial anisotropy of the data. For the purpose of identifying SGD locations, it is assumed that reduced bulk ground conductivity at the sediment surface indicates SGD with a fresh component. This assumes that the reduced conductivity is a result of a fresh, terrestrially-derived SGD driven by a hydraulic head of an aquifer persisting on land, an assumption that has been supported by seepage meter data (flow rate and salinity).

\subsubsection{Seepage measurements}

During the intercomparison experiment several types of seepage meters were deployed with the aim to study spatial and temporal variations of SGD from the back-reef lagoon at Flic-en-Flac coast. Manual seepage chambers of Lee (1977) type (one end of 200 L steel drum, fitted with a sample port and a plastic collection bag inserted into the sediment) were used. Water seeping through the sediment displaces water trapped in the chamber forcing it up through the port into the plastic bag. The change in volume of water in the bag over a measured time interval provides the flux measurement (Bokuniewicz et al., 2006).

Nine chambers were placed at a total of 28 locations (Fig. 2). Devices were deployed in three shore normal transects, one adjacent to a large visible submarine spring (site A), another about $1 \mathrm{~km}$ north of the spring (site B), and a third about $500 \mathrm{~m}$ south of the spring at the South beach (site C). In addition, along the $1500 \mathrm{~m}$ shoreline, low conductivity areas identified by the bulk conductivity mapping were targeted for manual seepage meter deployments. The first shore normal transect consisted of five devices located adjacent to the submarine spring. The shoreward device (M1) was placed at a depth of $50 \mathrm{~cm}$. The other four devices (M3, M6, M4, and M5) were located at distances of 20, 50, 80, and $150 \mathrm{~m}$ from the low-tide line, with the respective water depths at low tide of $1.6 \mathrm{~m}, 1.9 \mathrm{~m}, 1.4 \mathrm{~m}$, and $1.6 \mathrm{~m}$. The tops of the devices were between 0.04 and $0.1 \mathrm{~m}$ above the sea floor. The flushing time (in days) was calculated as height of the top of the chamber above the seafloor divided by the measured discharge rate. Measurements were taken at this transect over a period of 72 hours.

The second shore normal transect (consisting of five devices) was located at site B, an embayment on the northern end of the lagoon within the discharge zone of an ephemeral surface stream (Fig. 2). The shoreward device (B1) was placed at a depth of $30 \mathrm{~cm}$. The other four devices (B2, B3, B4 and B5) were placed at distances of $20,50,120$, and $250 \mathrm{~m}$ from the low-tide shoreline, and their respective water depths were $1.0 \mathrm{~m}, 1.2 \mathrm{~m}, 1.7 \mathrm{~m}$, and $2.1 \mathrm{~m}$. Two more devices were placed next to benthic chamber B1 and B2 used by other investigators for comparison. Measurements were taken at this transect over a period of 24 hours.

The third shore-normal transect was located at site C (Fig. 2). This transect consisted of three devices located within $30 \mathrm{~m}$ of the low tide shoreline. Beyond $30 \mathrm{~m}$, the sea floor was hard coral and chambers could not be placed there. The devices M23, M9 and M16 were located 7, 15, and $30 \mathrm{~m}$ from the shore at 
water depths of $0.8,1.0$, and $1.5 \mathrm{~m}$ respectively. Measurements were taken along this transect for a period of 10 hours.

Finally, the shore parallel transect consisted of measurements taken at various times from devices all located within $15 \mathrm{~m}$ of the low-tide line. This transect consisted of 18 devices that were operating for a period of 10 hours to 5 days. Not all measurements along this transect were made simultaneously, however, at least six devices along this transect were measuring SGD throughout the sampling period.

As manual seepage meters are very labor intensive, several types of automated seepage chambers have recently been developed (Krupa et al., 1998; Taniguchi and Iwakawa, 2001; Sholkovitz et al., 2003). To collect time series SGD data we used a continuous dye-dilution seepage meter (DSM) developed by Sholkovitz et al. (2003), and a heat type automated seepage meters (HSM) developed by Taniguchi et al. (2007). HSM were located around the submarine spring (site A), and at site B (Fig. 2). DSM operated at four locations within the Flic-en-Flac Lagoon (sites A, B, C and D, between March 21 and 24).

\subsection{Water sampling}

Water samples were collected from the back-reef lagoon, as well as in the open sea (Table 1). In the open sea samples were collected $\sim 0.5 \mathrm{~m}$ below the surface in two transects up to $5 \mathrm{~km}$ offshore, perpendicular to the coastline at Flic-en-Flac. The collected samples were stored in plastic bottles: $2 \times 0.2$ $\mathrm{L}$ (nutrients), $1 \mathrm{~L}\left(\delta^{2} \mathrm{H}, \delta^{18} \mathrm{O},{ }^{3} \mathrm{H}\right)$ and 10-100 L (Ra isotopes).

The seepage chambers were deployed a sufficient time to ensure they were well flushed and thus represented end-member water seeping from the sediments. Water samples were also collected from two seepage chambers located around the submarine spring ( 5 and $32 \mathrm{~m}$ from the shoreline). Information on seepage chambers is presented in Table 2.

Water samples were also collected from the temporary wells drilled into the public beach near the submarine spring (Fig. 3). The BH1 well was situated in front of the submarine spring, 4 meters from the low-tide water line (during the high tide the borehole site was covered with seawater). The $\mathrm{BH} 2$ and $\mathrm{BH} 3$ wells were $6 \mathrm{~m}$ and $4 \mathrm{~m}$ far from the BH1, forming an onshore transect. These wells were not inundated by seawater during high tides. Another transect of wells was drilled $10 \mathrm{~m}$ south and consisted of $\mathrm{BH} 4$, which was inundated at high tide, and BH5, $6 \mathrm{~m}$ onshore at the same site that remained dry during high tide. However, water could only be pumped from the two wells closest to the lagoon (BH1 and BH4). The depth of the wells was $60 \mathrm{~cm}$. Information on borehole wells is presented in Table 3 .

Groundwater samples were collected from inland commercial wells and from springs in the western part of Mauritius Island (Table 4). 


\subsection{Laboratory analyses}

\subsubsection{Stable isotopes}

Stable isotopes of hydrogen and oxygen were analyzed in the IAEA's Isotope Hydrology Laboratory (Vienna). $\delta^{2} \mathrm{H}$ analyses were done using the $\mathrm{H}_{2} \mathrm{O}-\mathrm{Zn}$ reduction method (Coleman et al., 1982). $\delta^{18} \mathrm{O}$ analyses were performed using the $\mathrm{CO}_{2}-\mathrm{H}_{2} \mathrm{O}$ equilibration procedure, as reported by Epstein and Mayeda (1953). The isotopic results were reported against the international standard VSMOW (Vienna Standard Mean Ocean Water) as defined by Gonfiantini (1978). The precision of measurements $(1 \sigma)$ was $\pm 0.1 \%$ for $\delta^{18} \mathrm{O}$ and $\pm 1 \%$ o for $\delta \mathrm{D}$.

\subsubsection{Tritium}

Tritium $\left({ }^{3} \mathrm{H}\right)$ in water samples was analyzed either by mass spectrometry using the ${ }^{3} \mathrm{H}-{ }^{3} \mathrm{He}$ in-growth method (Clark et al., 1976; University of Miami), or by electrolytical enrichment and liquid scintillation spectrometry (Groening et al., 2009; IAEA's Isotope Hydrology Laboratory, Vienna). The results are expressed in Tritium Units (1 TU represents a ratio of 1 tritium $\left({ }^{3} \mathrm{H}\right)$ atom to $10^{18}$ protium $\left({ }^{1} \mathrm{H}\right)$ atoms, which is equal to $118 \mathrm{mBq} / \mathrm{L}$ of water). IAEA reference materials are routinely analyzed and both labs participate in intercomparison exercises to ensure quality and consistency between analytical methods.

\subsubsection{Radium isotopes}

Radium isotopes were analyzed at South Carolina University (Columbia) by the method developed by Moore (1996) and Moore and Arnold (1996). Acrylic fibre, treated with a hot solution of saturated $\mathrm{KMnO}_{4}$, was used for pre-concentration of Ra isotopes from seawater samples (carried out in a field lab). After exposure to seawater, each Mn fibre sample was rinsed with Ra-free water to remove salts, dried with a stream of air and placed in a helium circulation system to sweep ${ }^{219} \mathrm{Rn}$ and ${ }^{220} \mathrm{Rn}$ generated by ${ }^{223} \mathrm{Ra}$ and ${ }^{224} \mathrm{Ra}$ decays in a scintillation cell, where alpha decay events from radon and daughter products are recorded. Longlived ${ }^{226} \mathrm{Ra}$ and ${ }^{228} \mathrm{Ra}$ were separated from the sample by leaching with hydrochloric acid and a stable barium carrier was added to co-precipitate $\mathrm{Ra}$ as $\mathrm{Ba}(\mathrm{Ra}) \mathrm{SO}_{4}$. This precipitate was transferred to a polypropylene tube, sealed and aged for three weeks to permit ${ }^{222} \mathrm{Rn}$ and daughters to equilibrate before analyzing ${ }^{226} \mathrm{Ra}$ and ${ }^{228} \mathrm{Ra}$ via gamma-spectrometry using a HPGe detector. The list of collected samples for isotope analyses is given in Table 5.

\subsubsection{Nutrients}

Nutrients, included nitrite, nitrate, silicate and phosphate, were analyzed in water samples collected from wells and the lagoon in the Flic en Flac area (Table 6). Replicate water samples were collected in plastic 
bottles (dissolved nitrate and soluble reactive silicate) and in glass bottles (reactive phosphate), stored at $4{ }^{\circ} \mathrm{C}$ and analyzed within $24 \mathrm{~h}$. The concentration of dissolved nitrite, nitrate, silicate and phosphate were determined using standard spectrophotometric methods (Parsons et al., 1984) at $543 \mathrm{~nm}, 810 \mathrm{~nm}$ and $882 \mathrm{~nm}$, respectively, using a PU 8710 spectrophotometer and a UNICAM 8700 Series UV/VIS spectrometer following calibration with standard solutions. Quality control was achieved by analyzing internal reference materials, independently prepared from standard solutions. The standard curves were verified by analyzing a standard solution (concentration within the linear range of samples) every 10 samples.

\section{Results and discussion}

A weather station at the field site made continuous measurements of air temperature, wind speed and direction, rainfall, and barometric pressure during the intercomparison study (Fig. 4). This data is useful in interpreting the surface mapping data, and in particular the lagoon salinity pattern. Wind speed was used to correct for gas exchange in the radon SGD model, and was fairly high ( $>5 \mathrm{~m} / \mathrm{s})$ almost every afternoon. The passage of cyclone Hennie on March 24 resulted in drastic drop in barometric pressure, significant rainfall and sustained winds of $>15 \mathrm{~m} / \mathrm{s}$.

\subsection{SGD characterization}

\subsubsection{Hydrologic characterization}

The freshwater component of SGD on a regional scale representing the coastal discharge zone for the main portion of the aquifer was derived by hydrological methods. The driving force for discharge of fresh SGD is the inland hydraulic head. This component of SGD was quantified using a traditional hydrologic approach over the $8 \mathrm{~km}$ regional scale of the coastline that is the main discharge zone for the Curepipe aquifer. Freshwater SGD was estimated by constructing a water budget with data from a network of monitoring wells, stream gauging stations, and meteorological stations, which have been established on the island to collect a variety of data related to both groundwater and surface water. A water budget calculates the inputs to the hydrologic system in terms of precipitation, and subtracts outputs (evapotranspiration, surface runoff, groundwater pumping) to produce an estimate of remaining groundwater that is expected to discharge at the coastline, within and beyond the lagoon.

Rainfall is seasonal on Mauritius, varying from an average maximum of $310 \mathrm{~mm} / \mathrm{month}$ during the rainy season (December to April) to an average minimum of $75 \mathrm{~mm} /$ month during the dry season. For the Curipipe Aquifer, rainfall is about $4000 \mathrm{~mm} / \mathrm{y}$ near the groundwater divide on the central plateau, and decreases with topography to about $800 \mathrm{~mm} / \mathrm{y}$ near Flic-en-Flac (Giorgi et al., 1999). 
Evapotranspiration ranges from $1400 \mathrm{~mm} / \mathrm{y}$ on the cloudy, high central plateau to $2200 \mathrm{~mm} / \mathrm{y}$ near Flic-en-Flac (Proag, 1995). Surplus rainfall (rainfall in excess of evapotranspiration) is about $70 \mathrm{~mm} / \mathrm{y}$ along the coast (Medine meteorological station), $840 \mathrm{~mm} / \mathrm{y}$ halfway inland (Vacoas meteorological station), and 2,160 mm/y on the central plateau (Union Park meteorological station) (Proag, 1995). This excess rainfall would go either to surface runoff or groundwater recharge.

Surface runoff is considerable at some regions of Mauritius, particularly where the Older series lava flows outcrop at the ground surface. On the other hand, the Curipipe Aquifer is covered with highly permeable Younger series lava flows, and consequently has almost no surface runoff. The majority of the water infiltrates through the permeable geologic materials and there are no streams large enough to gauge within the groundwater basin. Because of this, surface runoff can be neglected from the water budget calculation (there are only two small rivers about $20 \mathrm{~km}$ south of the study site - the Riviere Rempart and Riviere Noire). Therefore the excess rainfall described above is considered to go to groundwater recharge.

Groundwater recharge was estimated by dividing the Curipipe Aquifer into five regions of $19 \mathrm{~km}^{2}$ each. The excess rainfall was allocated to each of these regions at $70,450,840,1500$, and $2160 \mathrm{~mm} / \mathrm{y}$. Multiplying the excess rainfall times the surface area for each region produces a total estimated groundwater recharge of $9.5 \times 10^{7} \mathrm{~m}^{3} / \mathrm{y}$.

Groundwater pumping estimates are known with the least certainty. The Mauritius Water Resources Unit provided data on groundwater pumping for 2004 for five of the major water supply wells within the basin. The extraction rate for these five wells for 2004 was $2.4 \times 10^{6} \mathrm{~m}^{3} / \mathrm{y}$. An additional 36 wells are identified as being in use in the basin (MPW, 2003). Assuming similar pumping rates for these wells, a total of $2.0 \times 10^{7} \mathrm{~m}^{3} / \mathrm{y}$ of water is pumped from the Curipipe Aquifer. Thus the hydrologic estimate of potential fresh groundwater recharge is $9.5 \times 10^{7} \mathrm{~m}^{3} / \mathrm{y}$. Subtracting the groundwater pumping from the estimated recharge leaves an estimated freshwater discharge at the shoreline of $7.5 \times 10^{7} \mathrm{~m}^{3} / \mathrm{y}$.

\subsubsection{Salinity as a tracer}

Salinity is tracer of fresh SGD (in the absence of other sources of fresh water, such as rivers, runoff or precipitation). Offshore water column salinity and temperature profiles indicate the water column was well stratified but there were small differences between the sites (between 32.6 in the lagoon and 34.66 in the open ocean, Table 1, Fig. 5). No profiles were possible in the lagoon due to the shallow water depth $(\sim 1 \mathrm{~m})$. However surface salinity mapping was possible and identified several areas of lower salinity including: in the northern lagoon close to the Klondike hotel (site D); in the northern lagoon near site B; close to the submarine spring (site A); and at the South beach (site C) (Fig. 6). Reduced salinity was observed at site A, the location of the submarine spring, on March 18 and 20, whereas a significant freshening at site B was only observed on March 18. On March 24, during cyclone Hennie's passage over 
the field site, the low salinity signature of the submarine spring at site A could not be distinguished from lagoon surface waters due to a substantial freshening of lagoon waters from cyclone-induced rainfall. However, it was possible to distinguish fresh discharge at site B during passage of the cyclone. A slight, but systematic increase in surface temperature towards the northern end of the lagoon was observed, indicating a higher residence time and restricted exchange with offshore waters at the northern end of the lagoon.

Surface water salinity in the immediate vicinity of submarine springs is significantly lowered. A large spring at site A, within the lagoon, lowered the surface water salinity to 4-6, compared to an average lagoon salinity of 34.5 (Table 1). Another submarine spring at Pointe aux Sables (outside the lagoon about $2 \mathrm{~km}$ to the north) also lowered the surface salinity (to 30.5 ).

Information on seepage chambers, results on conductivity, salinity and temperature measurements, are presented in Table 2. Water samples from seepage chambers showed large variations in temperature and salinity that were highly dependent on the location of the chamber. As expected, water samples collected from chambers positioned close to the submarine spring (site A) showed the lowest salinities with chamber water increasing in salinity with distance from the coast. Ambient lagoon salinity was over 35 , but benthic chamber water samples had salinities as low as 3.2. An inverse correlation was seen between salinity and SGD rates (Fig. 7). Below a flow rate of $40 \mathrm{~cm}^{3}$ of water per $\mathrm{cm}^{2}$ of sea floor per day $(\mathrm{cm} /$ day), the seepage device water had virtually the same salinity as ambient seawater, suggesting discharging water was recirculated seawater. Fairly high flow rates (between 100 and $170 \mathrm{~cm} /$ day) were found at intermediate salinities between 10 and 20 . Above $210 \mathrm{~cm} /$ day the salinity of the discharged water flattens out at 5 . This is the same salinity as measured directly at the submarine spring.

\subsubsection{Seepage rate measurements}

The rate and distribution of SGD was measured using vented benthic chambers on the floor of the shallow Flic-en-Flac lagoon on the west coast of Mauritius Island (Fig. 2). Discharge rates as high as 490 $\mathrm{cm} /$ day were observed near the spring. However, more typical values for the Flic-en-Flac Lagoon were in the range of 5 to $15 \mathrm{~cm} /$ day. High SGD rates were associated with low pore water conductivity in the region of the submarine spring. Large variations in SGD rates were seen over distances of a few meters. We attribute variations to the geomorphologic features of the fractured rock aquifer underlying a thin blanket of coral sands, as well as to the presence of lava tubes leading to sites of high discharge. Clustering of fractures and the topography of the rock-sediment interface may serve to focus or disperse groundwater discharge.

For the alongshore transect, 18 seepage meters were deployed, all located within $15 \mathrm{~m}$ of the low-tide line (Fig. 2). The mean flow rate along this transect was $55 \mathrm{~cm} /$ day. If integrated over the entire length of 
the transect, total discharge is $220 \mathrm{~m}^{3}$ per meter of the shore per day. These measurements probably overestimate SGD because of the very high values observed near the submarine spring. If the calculation is revised using only the measurements from the offshore transect by the north cove, the integrated SGD would be $35 \mathrm{~m}^{3} / \mathrm{m}$ day. Seepage meter transects out into the lagoon (up to $400 \mathrm{~m}$ ) show similar rates of discharge in the entire lagoon, thus there is no decrease (or increase) with distance from the shore (Fig. 8).

All of the manual seepage meters in the alongshore transect (Fig. 2) were deployed in a homogenous, and presumably permeable, carbonate sand. At $10 \mathrm{~m}$ south and shoreward of the submarine spring, SGD was $216 \mathrm{~cm} /$ day. At the same distance north of the spring, SGD rates were 5 to $15 \mathrm{~cm} /$ day, more typical of the rest of Flic-en-Flac Lagoon (Fig. 9). At other locations, a modulation of SGD with tidal elevation is often, but not always, found with higher seepage rates occurring at low tide. Such a pattern was not evident in the majority of manual seepage meter time series measurements (however, see discussion of DSM type seepage meter time series below). The meter at M6, near the main submarine spring with the highest seepage rates, did show an inverse correlation with tidal elevation, but the relationship is weak (Fig. 10). Fluctuation of seepage rates was observed as abrupt increases (or decreases), which would then persist at the new levels, for no obvious reason.

The mean SGD fluxes measured around the submarine spring (Fig. 2) by continuous heat type automated seepage meters were between 40 and $50 \mathrm{~cm} /$ day, and $25 \mathrm{~cm} /$ day at site $\mathrm{B}$. The temporal and spatial distribution of SGD conductivity was measured with a CTD sensor inserted into the camber of the seepage meter. The conductivity of the water inside the chambers varied along the $50 \mathrm{~m}$ distance between $5.63 \mathrm{mS} / \mathrm{cm}$ (salinity 3.0 ) and $50.53 \mathrm{mS} / \mathrm{cm}$ (salinity 30.9), indicating the seepage of fresh groundwater near the spring. The temperature of discharging water close to the spring was lower $\left(25.3^{\circ} \mathrm{C}\right)$ compared to $28.8^{\circ} \mathrm{C}$ in the lagoon.

The longest seepage rate time series were completed with the dye-dilution seepage meter (DSM). Four locations within the Flic-en-Flac Lagoon (Fig. 2) were occupied between March 21 and 24, 2005: on March 21, the DSM was deployed at site B (6 hours, Fig. 11a); on March 22 the DSM was deployed just north of the submarine spring ( 9 hours, Fig. 11b); on March 23 the meter was placed near the manual seepage meter M9 along the beach south of the spring (4 hours, Figure 11c); and the longest deployment (March 23 to 24, 22 hours) was at the northern edge of the lagoon in front of the Klondike Hotel (Fig. 11d). During deployment of the DSM, CTD's were emplaced within the seepage chamber to record salinity changes and also external to the chamber, to capture variations in salinity and depth associated with the tidal phase. At site B, seepage rates varied from 2 to $21 \mathrm{~cm} /$ day, with increased flow coincident with low tide (Fig. 11a). Lagoon surface water displayed a freshening to about 31 at low tide, a drop of 1.5. Chamber salinity did not change dramatically $(\sim 32.5)$, indicating that seepage into the chamber did not have significant freshwater component. At the site north of the submarine spring, there was no clear 
correlation between seepage and tidal cycle (Fig. 11b). Over the course of the falling tide, flow ranged from -5 to $5 \mathrm{~cm} /$ day. Again lagoon surface water salinity and tidal height drop concurrently. The 4 hour deployment adjacent to the manual seepage meter M9 occurred on a rising tide and flow rates ranged from 6 to $22 \mathrm{~cm} /$ day (Fig. 11c). At this site, the relationship between tidal height and lagoon salinity is less clear, and again internal chamber salinity does not change. The deployment at site $\mathrm{D}$ provides the longest record of SGD flow with rates between 0.4 and $28 \mathrm{~cm} /$ day over two tidal cycles (Fig. 11d). The highest flow rates appear to occur on falling tides shortly before low tide. This deployment coincided with the arrival of tropical storm Hennie, which brought increased rainfall and wind speeds $(>15 \mathrm{~m} / \mathrm{s})$. The freshening of lagoon salinity (a drop of 10 over two tidal cycles) is likely due to the increased precipitation and local surface run-off. The chamber salinity exhibits a less dramatic drop (5 over the same period), which is most likely due to mixing of seepage with a freshwater component with the original, higher salinity contents of the seepage meter. Lagoon water and chamber salinity were recorded beyond the deployment of the spectrophotometer portion of the automated seepage meter (removed due to a rough sea). Ambient salinity rises again once the rainfall has ceased, as does inner chamber salinity, suggesting either that seepage has an increased salinity or possibly reverse flow of lagoon water into the sediments (and chamber). Since no flow data is available for this time period, it is not possible to distinguish between these two possibilities.

The multiple deployments of the DSM (Fig. 2) captured the spatial and temporal variability of SGD within Flic-en-Flac Lagoon (Fig. 11). SGD was saline at three locations (site B, immediately north of the submarine spring and M9, to the south of the spring), while there was a fresh component to the seepage at site D. Reverse seepage was only observed north of the submarine spring, which may be a site of seawater recirculation into the sediments and potentially a source of seawater to the submarine spring, where discharging water has a salinity around 5, indicating mixing between freshwater and seawater occurs within the sediments. The average seepage from all deployments of the DSM was $10.5 \mathrm{~cm} /$ day.

\subsubsection{Stable isotopes and tritium}

\section{Seawater samples}

The isotope composition of seawater samples is characterized by significant variability and enrichment in heavy isotopes mainly due to evaporation processes in the sea, and is clearly differentiated from the groundwater end-member. Seawater $\delta^{2} \mathrm{H}$ ranged from 0.9 to $4.3 \%$, and $\delta^{18} \mathrm{O}$ ranged from -0.5 to $0.6 \%$ (Table 1). Tritium levels varied between $0.89 \mathrm{TU}$ (lagoon) and $0.80 \mathrm{TU}$ (the open sea). These results are comparable with the open Indian Ocean data $\left(\delta^{2} \mathrm{H}=4.3 \% ; \delta^{18} \mathrm{O}=0.6 \%\right.$ and ${ }^{3} \mathrm{H}=0.82 \mathrm{TU}$; Povinec et al., 2003, 2004). There was no correlation between tritium levels and sampled water depth, which varied between 1 and $40 \mathrm{~m}$. 


\section{Water samples from seepage chambers and boreholes}

Results on isotopic analysis of water samples from seepage chambers are presented in Table 2. The water samples fall along a mixing line between seawater and groundwater end members (Fig. 12). $\delta^{2} \mathrm{H}$ varied between -15.5 and $5.1 \%$ and $\delta^{18} \mathrm{O}$ between -2.8 and $0.6 \%$, indicating that SGD is a mixture of recirculated seawater and varying amounts of fresh groundwater. Tritium concentration measured in seepage chambers varied between 0.65 and 0.98 TU (Table 1).

Water samples from the wells drilled into the beach during the field study (Table 3) were similar in isotopic composition to water collected from wells and seepage chambers $\left(\delta^{2} \mathrm{H}\right.$ between -17.3 and 10.6 $\%$, $\delta^{18} \mathrm{O}$ between -3.1 and $-1.9 \%$, Fig. 12). Tritium levels in drilled wells varied between 0.69 and 0.98 TU (Table 2).

\section{Rain and groundwater samples}

The stable isotope and tritium results of rainwater and groundwater samples are presented in Table 4 . The rainwater isotopic composition $\left(\delta^{18} \mathrm{O}-5.3 \%\right.$ and $\delta^{2} \mathrm{H}-35.6 \%$ ) shows (Fig. 12) that this sample is depleted both in $\delta^{2} \mathrm{H}$ and $\delta^{18} \mathrm{O}$. When comparing this result with our previous studies (e.g. offshore Ubatuba, Brazil (Povinec et al., 2008b)), this sample is very depleted both in $\delta^{2} \mathrm{H}$ and $\delta^{18} \mathrm{O}$ (the values for Brazil were $-17.5 \%$ and $-3.5 \%$, respectively). The measured values are, however, still within the expected range for the Indian Ocean (from $-38 \%$ to $-6 \%$, and from $-6 \%$ to $-2 \%$ to respectively), as indicated by the IAEA's GNIP (Global Network of Isotopes in Precipitation) database (http://www.iaea.org). The tritium level (1.55 TU) was higher than for all other samples $(<1.1 \mathrm{TU})$, as expected.

The $\delta^{2} \mathrm{H}$ of groundwater springs and wells ranged from -21.6 to $-14.8 \%$, while the $\delta^{18} \mathrm{O}$ values were between -3.6 and $-2.9 \%$. There were not large differences in $\delta^{2} \mathrm{H}$ and $\delta^{18} \mathrm{O}$ values in samples collected in 2004 and 2005. The large gap between the rainwater and groundwater results (Fig. 12), and a low slope in the $\delta^{2} \mathrm{H}$ vs. $\delta^{18} \mathrm{O}$ relationship when compared with the Global Meteoric Water Line (GMWL), defined by Craig (1961) as

$$
\delta^{2} \mathrm{H}=8 \delta^{18} \mathrm{O}+10
$$

may be due to isotopic fractionation upon groundwater infiltration and its underground circulation (Schiavo et al., 2009). Tritium levels in wells and springs ranged from 0.30 to $1.13 \mathrm{TU}$. The groundwater well (W08), within $5 \mathrm{~km}$ of site A, showed the lowest stable isotope values (-3.6\% for $\delta^{18} \mathrm{O},-21.6$ for $\delta^{2} \mathrm{H}$ and $0.30 \mathrm{TU}$ for ${ }^{3} \mathrm{H}$ ), and is a potential groundwater end-member candidate (Table 4). 


\section{Isotopic characterization of SGD}

A plot of $\delta^{18} \mathrm{O}$ and $\delta^{2} \mathrm{H}$ for all samples clearly demonstrates end member mixing between fresh, terrestrially sourced groundwater and seawater, with water from wells, springs and seepage meters falling on the mixing line (Fig. 12). Note that almost all samples analyzed are below the GMWL. While seawater samples are highly enriched in ${ }^{18} \mathrm{O}$, groundwater samples are depleted in ${ }^{18} \mathrm{O}$ with respect to the VSMOW. Samples collected in seepage meters are located between these two main groups, representing mixtures of groundwater and seawater, and indicating that a re-circulation of seawater is playing a dominant role there.

The tritium data is most useful for distinguishing different groundwater types since SGD and seawater have similar values (Fig. 13). $\delta^{18} \mathrm{O}$ of SGD vary between groundwater and seawater endmembers. Because of radioactive decay $\left(12.32\right.$ y) ${ }^{3} \mathrm{H}$ levels vary between rainwater and old groundwater. It is possible to identify three groundwater types: (i) young waters (1.2 TU), comparable to rain water (1.6 TU); (ii) medium-age waters ( $0.8 \mathrm{TU}$ ); and (iii) older water with ${ }^{3} \mathrm{H}$ level at $0.30 \mathrm{TU}$.

When comparing tritium results (Fig. 13) one can notice that there is a gap in TU values between the rain water (1.5 TU) and others (wells, seepage, borehole and SGD samples - all below $1.1 \mathrm{TU}$ ), indicating that all these samples represent older waters, or their mixtures with seawater. The submarine spring belongs to the medium-age water group as well.

It is possible to calculate the contribution of fresh, terrestrially sourced groundwater to submarine discharge using a simple two end-members mixing model. Using a groundwater end-member from well W08 ( $5 \mathrm{~km}$ west of site $\mathrm{A}, \delta^{2} \mathrm{H}=-21.6 \% ; \delta^{18} \mathrm{O}=-3.6 \% ;{ }^{3} \mathrm{H}=0.3 \mathrm{TU}$ ), and a seawater end-member from the open Indian Ocean $\left(\delta^{2} \mathrm{H}=4.3 \%\right.$; $\delta^{18} \mathrm{O}=0.6 \%$ and ${ }^{3} \mathrm{H}=0.82 \mathrm{TU}$; Povinec et al., 2003, 2004), the contribution of fresh groundwater to SGD varied from a few \% to almost $100 \%$ (in the case of the M1 chamber with $\delta^{2} \mathrm{H}=-15.5 \%$; $\delta^{18} \mathrm{O}=-2.8 \% ;{ }^{3} \mathrm{H}=0.65 \mathrm{TU}$ ), depending on the location and the tidal phase. Depleted values were observed only in the borehole well $\mathrm{BH} 1 / 1\left(\delta^{2} \mathrm{H}=-17.3 \% ; \delta^{18} \mathrm{O}=-3.1 \%\right.$; however, high $\left.{ }^{3} \mathrm{H}=0.98 \mathrm{TU}\right)$. The rest in the SGD balance should be a mixture of groundwater and seawater recirculating in the system (as documented in Fig. 12).

The SGD may be therefore represented by coastal groundwater and re-circulated seawater with different proportions of groundwater in the mixture. Mauritius Island, when compared with other visited sites for SGD investigations (e.g. east coast of Sicily, east coast of Brazil), represents the case with much larger contribution of terrestrial groundwater in the SGD, which has important implications for the management of groundwater on the island.

\subsubsection{Radium isotopes}

Radium isotopes were analyzed in groundwater samples collected from wells and flowing springs, from dug pits on the beach, in surface lagoon water, and in offshore waters. The results are presented in Table 5. 
For reference to expected open ocean values for long-lived isotopes $\left({ }^{226} \mathrm{Ra}\right.$ and $\left.{ }^{228} \mathrm{Ra}\right)$ we used radium data from two GEOSECS Indian Ocean stations (425 and 426) located near Mauritius Island. These samples, collected in January 1976, showed ${ }^{226} \mathrm{Ra}$ levels of 1.22 and $1.30 \mathrm{mBq} / \mathrm{L}$, and 0.58 and $0.75 \mathrm{mBq} / \mathrm{L}$ for ${ }^{228} \mathrm{Ra}$, respectively. Compared to these samples, the ones collected within 1-3 km of Mauritius in 2005 are slightly enriched in ${ }^{226} \mathrm{Ra}$, but not enriched in ${ }^{228} \mathrm{Ra}$. The average ${ }^{226} \mathrm{Ra}$ content in the 6 samples collected 1-3 km from the coast is $1.38 \mathrm{mBq} / \mathrm{L}$ (10\% enrichment); for ${ }^{228} \mathrm{Ra}$ it is $0.62 \mathrm{mBq} / \mathrm{L}$ (slightly less than the GEOSECS average).

The samples collected in the lagoon were similarly enriched in ${ }^{226} \mathrm{Ra}$, but not enriched in ${ }^{228} \mathrm{Ra}$ relative to offshore waters. To analyze the long-lived Ra isotopes in the lagoon submarine spring, we combined samples Spring 1, 2a and $2 \mathrm{~b}$ (Table 5) to yield a sampled volume of $45 \mathrm{~L}$. This sample is actually depleted in ${ }^{226} \mathrm{Ra}$ and ${ }^{228} \mathrm{Ra}$ with respect to the lagoon and ocean water samples. The significance of the Ra depletion will be discussed later.

One water sample collected from the pit dug on the beach was significantly depleted in ${ }^{226} \mathrm{Ra}$ and one was enriched with respect to surface waters. The ${ }^{228} \mathrm{Ra}$ activity was not measurable in these 10 liter samples. We did not analyze the long-lived isotopes in the well samples, but based on the extremely low activities of the short-lived isotopes in these samples, we do not expect them to be enriched or even measurable.

The samples from the lagoon were enriched in ${ }^{224} \mathrm{Ra}$ compared to the offshore samples, the submarine spring, dug pits on the beach, and groundwater wells. For ${ }^{223} \mathrm{Ra}$, the lagoon is enriched with respect to the offshore samples, but the spring and pit samples are slightly higher than the lagoon. Samples from the wells are below detection with one exception.

The lack of significant enrichment of the long-lived isotopes means that the use of these isotopes as an index of SGD is not applicable to the chosen site in Mauritius. There may be other sites on the island where springs or other SGD sources are enriched, but we did not find them. The fact that the spring was actually depleted relative to offshore waters does not offer much hope for other sites. The very low enrichments in radium probably reflect the low abundance of $U$ and $T h$ in the basalt that makes up the island.

The enrichment of ${ }^{224} \mathrm{Ra}$ and ${ }^{223} \mathrm{Ra}$ in the lagoon relative to offshore waters may indicate a source of SGD that is enriched in these short-lived isotopes. However, the spring was depleted relative to the lagoon in ${ }^{224} \mathrm{Ra}$. This suggests that the enrichment in the lagoon is due to regeneration and loss of ${ }^{224} \mathrm{Ra}$ isotopes from ${ }^{228} \mathrm{Th}$ in the fine-grained sediments. The spring and lagoon have almost the same ${ }^{223} \mathrm{Ra}$ activity, yet the salinity of the spring is considerably lower. Thus, mixing of spring water with high salinity offshore water cannot explain the ${ }^{223} \mathrm{Ra}$ activity of the lagoon. Either there is an unknown high salinity SGD source or the excess ${ }^{224} \mathrm{Ra}$ comes from sediments.

\subsubsection{Nutrients}


All anthropogenic activity in the catchment region, including agriculture and tourism, has a potential impact on water quality in the Flic-en-Flac Lagoon. The terrestrial groundwater that is the source of fresh SGD only filters through a thin blanket of unconsolidated sediment before entering the fractured bedrock aquifer system. The major input of dissolved nitrate and silicate to Flic-en-Flac Lagoon is from terrestrially sourced fresh groundwater driven by the inland aquifer head and from local run-off/discharge during periods of heavy rains. Phosphate and nitrate apparently may originate from domestic effluents which have not been treated well in a local sewage system.

Concentrations of dissolved nitrite were below $10 \mu \mathrm{g} / \mathrm{L}$ in wells, lagoon and open sea water, but 20.8 $\pm 23.5 \mu \mathrm{g} / \mathrm{L}$ in seepage chambers (Table 6). Concentrations of dissolved nitrate were $4660 \pm 2820 \mu \mathrm{g} / \mathrm{L}$ in wells, $910 \pm 1390 \mu \mathrm{g} / \mathrm{L}$ in seepage chambers, $1330 \mu \mathrm{g} / \mathrm{L}$ in drilled wells, $159 \pm 137 \mu \mathrm{g} / \mathrm{L}$ in lagoon waters, and $161 \pm 71 \mu \mathrm{g} / \mathrm{L}$ in offshore waters. Concentrations of dissolved phosphate were $42.5 \pm 29.6$ $\mu \mathrm{g} / \mathrm{L}$ in wells, $47.0 \pm 33.6 \mu \mathrm{g} / \mathrm{L}$ in seepage chambers, $115 \pm 64 \mu \mathrm{g} / \mathrm{L}$ in drilled wells, $<10 \mu \mathrm{g} / \mathrm{L}$ in lagoon waters and offshore waters. Concentrations of dissolved silicate were $9900 \pm 1670 \mu \mathrm{g} / \mathrm{L}$ in wells, $1480 \pm$ $1490 \mu \mathrm{g} / \mathrm{L}$ in seepage chambers, $1620 \pm 90 \mu \mathrm{g} / \mathrm{L}$ in drilled wells, $271 \pm 144 \mu \mathrm{g} / \mathrm{L}$ in lagoon waters, and $22500 \pm 4900 \mu \mathrm{g} / \mathrm{L}$ in offshore waters.

The high SGD rates observed in the Flic-en-Flac Lagoon may lower the lagoon's assimilative capacity, enhancing the potential problem of high nutrient concentrations and associated eutrophication. Dissolved nutrients may also undergo a series of transformation processes due to dilution and degradation in the lagoon. Silicate concentrations in fresh-water systems were inversely linked with flow, reflecting large scale catchment processes observed in the region, i.e. a longer residence time would indicate a lower flow-rate resulting in higher silicate concentration. Silicate is conservative with respect to salinity in the lagoon because no internal processes affect silicate cycling within the lagoon. The end-member fresh groundwater silicate concentration is fixed by dissolution and mineral equilibrium with aquifer solids.

Dissolved nitrate, silicate and phosphate concentrations in the wells, in SGD and in the lagoon (Table 6) indicate that water resources in the region are heavily influenced by agricultural activities and the release of domestic waste. Nitrate concentrations were negatively correlated with flow and were significantly higher during this field study than those reported for a year with higher rainfall and presumably shorter water residence times within the aquifer (Ramessur et al., 2001). They reflected agricultural land use and land practice changes which have had negative impacts on water quality. Offshore concentrations fell within the range of seawater values as cited by Naidu et al. (1991) for the Pacific region.

\subsection{Spatial distribution of $S G D$}




\subsubsection{Near-shore radon survey}

Radon surveys in the lagoon were made on the first two days of the experiment to determine if there were areas of interest based on the ${ }^{222} \mathrm{Rn}$ observations. The radon survey (Fig. 14) carried out close to the shoreline indicated high activity concentrations (up to $0.33 \mathrm{~Bq} / \mathrm{L}$ of water) surrounding the submarine spring (Fig. 2). High ${ }^{222}$ Rn concentrations were also observed off an area to the south (site C) and to the north (site B) of the spring. The radon data indicates that radon in the lagoon was not at a steady-stay condition represented by a saturated radon concentration. This can be expected due to low water level in the lagoon $(1 \mathrm{~m})$. Informed by the near shore survey, three locations were chosen for time-series radon measurements: near the submarine spring (site A), to the south (site C) and at site D in the northern part of the lagoon. Temporal variations of SGD as measured by radon monitors are discussed in detail in section 4.3.

\subsubsection{Near-shore ground conductivity surveys}

After identifying regions of reduced surface water salinity at site B with CTD-salinity mapping (Fig. 6), a more detailed investigation of the site was completed with a survey of bulk ground conductivity on a shore-normal transect. A transect was completed twice at two different tidal stages on the same day (Fig. 15). A landward migration of the low/high conductivity interface was observed at low tide. If tidal forcing was a dominant driver of SGD at this site, a seaward migration of the low/high conductivity interface would be expected due to increased hydraulic head at low tide. This suggests that variations in fresh discharge respond to changes in the aquifer height, driven by precipitation and recharge in the 12 hour period prior to the measurements rather than to tidal forcing.

Numerous seepage meters were installed in an alongshore transect just offshore of the fresh/salt interface at Site B for a $24 \mathrm{~h}$ period (distance $>15 \mathrm{~m}$ from high tide mark, Fig. 2). Bulk ground conductivity from $10 \mathrm{~m}$ to $85 \mathrm{~m}$ along transect was consistently greater than $14 \mathrm{mS} / \mathrm{cm}$, indicating that no terrestrially-derived component contributed to SGD further offshore than $9 \mathrm{~m}$. We conclude from this evidence that seawater recirculation is the main driver of SGD at distances $>10 \mathrm{~m}$ from the high tide line. This observation is consistent with the seepage meter measurements at site $\mathrm{B}$; water collected in manual seepage meters along this offshore transect was consistently of seawater salinity.

The bulk ground conductivity of the near-surface sediment was also investigated in an area surrounding the spring (6 m water depth) in a rectangular grid with $5 \mathrm{~m}$ and $10 \mathrm{~m}$ spacing in EW and NS directions, respectively (Fig. 16), as coral cover permitted (the spring is surrounded by a coral assemblage dominated by Acropora formosa). Despite the gaps in coverage, the bulk ground conductivity indicates that freshwater is flowing through sediments $\sim 60 \mathrm{~m}$ offshore and $\sim 80 \mathrm{~m}$ along shore around the spring. 
The bulk ground conductivity measurements in the vicinity of the spring appeared to reinforce the negative correlation between salinity and discharge (Fig. 17). A decrease in bulk ground conductivity in both the alongshore and offshore directions corresponded to an increase in the mean flow rates. The bulk ground conductivity measurements had also high spatial variability (in agreement with direct measurements of SGD made with the seepage devices). The observations are consistent with a connection of a landward aquifer to the near-shore zone via a lava tube or similar preferential flow path of volcanic origin. It is interesting to note, that locals report the existence of the spring for over $25 \mathrm{y}$, as well as distinct absence of other (major) sources within the lagoon.

The shallow structure $(1 \mathrm{~m})$ of the discharge zone with depth was investigated along a shore-normal transect (Fig. 18). There was little variation in conductivity with depth observed in the shallow sediment around the spring, suggesting fresh water was flowing upward from a deeper source. In addition, there was little change in bulk conductivity with depth in sediments outside of the spring influence. The transects completed at low and high tide are quite similar, suggesting that tidal pumping does not affect discharge immediately at the spring. The bulk ground conductivity distribution is in good agreement with the manual seepage meter observations.

We conclude that the discharge of terrestrially derived fresh groundwater into the northern region of Flic-en-Flac Lagoon appears to occur at two discrete locations. At site A, the large submarine spring discharges over an area of about $4800 \mathrm{~m}^{2}$ surrounding the main spring. The geophysical data (as well as seepage meter data reported earlier) suggests that discharge has been continuous, at least over the investigated time period. Site B is situated in a topographically narrow area to the north of the spring, where the geophysical data shows a freshening of beach pore water extending at most no further into the lagoon than $10 \mathrm{~m}$ from the high tide line. Response of this system to a local rainfall event was rapid, with recharge apparently dominating over tidal forcing. It is thus suggested that discharge from this aquifer is minor in magnitude, and not continuous.

\subsection{Temporal variations of SGD as measured by radon monitors}

We shall discuss now temporal variations of SGD as measured by radon monitors. Due to adverse weather conditions (tropical storm Hennie), it was not possible to deploy the radon equipment for a complete tidal cycle at any of the stations investigated. From measured radon concentrations we constructed time-series plots of radon inventories (multiplying the concentration by water depth, assuming a well-mixed layer in these shallow coastal waters). The first set of time-series measurements was collected with the continuous radon monitor deployed from a boat moored just 50 meters north of the submarine spring in the lagoon (site A). Measurements were made over several hours during a falling 
tide. The results presented in Fig. 19a show very high inventories (up to about $670 \mathrm{~Bq} / \mathrm{m}^{2}$ ). Three periods were observed that had systematic increases in radon inventories with very similar slopes $\left(4-5 \mathrm{~Bq} / \mathrm{m}^{2}\right.$ $\min )$.

The second deployment of the radon monitor was at site C. The inventories were much lower here (up to $\sim 70 \mathrm{~Bq} / \mathrm{m}^{2}$ ) and there was one period of a systematically increasing trend of radon inventory that occurred during the later stages of a falling tide (Fig. 19b).

The final radon monitoring at site D was cut short when tropical storm Hennie approached the island. The inventories measured here were intermediate between the last two sites (maximum $200 \mathrm{~Bq} / \mathrm{m}^{2}$ ) and showed a systematic increasing trend of inventory over time during a falling tide (Fig. 19c). Interestingly, the main indication of active seepage in the inventory versus time plot occurred at about the same stage in the tidal cycle as the previous experiment at site C (Fig. 19b).

\subsection{Estimation of SGD fluxes}

\subsubsection{Estimation of SGD fluxes from radon measurements}

Net ${ }^{222} \mathrm{Rn}$ fluxes were determined by evaluating the change in inventories over each measurement interval after making appropriate allowances for tidal fluctuations and atmospheric input. Mixing with offshore waters was estimated based on inspection of the calculated radon net fluxes or independently by use of short-lived Ra isotopes. Assuming that benthic fluxes of radon are driven mainly by groundwater (pore water) advection, one can convert calculated ${ }^{222} \mathrm{Rn}$ fluxes to water fluxes by dividing them by the measured radon concentration in groundwater. To make appropriate corrections, we also continuously monitor water depth, water temperature, weather conditions (wind speed, temperature, etc.), and atmospheric ${ }^{222} \mathrm{Rn}$ concentrations.

As it was not possible to deploy the radon equipment for a complete tidal cycle at any of the stations investigated, we thus modified our approach in estimation of SGD fluxes. Periods when there were systematic increases in radon inventories were regressed to estimate radon fluxes (a slope of the inventory versus time plot). Assuming that these fluxes were due largely to advection of radon-rich pore waters (groundwater), we then estimated flow by dividing the fluxes by measured groundwater concentrations. Samples collected from piezometers and shallow pits drilled on the beach (site A) showed radon concentrations between $5-9 \mathrm{~Bq} / \mathrm{L}$.

Based on the slopes of the regressions in the time-series of radon inventories (labeled "a", "b", and "c" in Fig. 19a), and whether the upper or lower groundwater radon concentration estimate was applied, we estimated that seepage rates through the sandy sediments near the spring ranged from 65 to 140 $\mathrm{cm} /$ day. A comparison to the 3 manual seepage meters that were closest to the radon monitoring site (M2, M15, and M6) shows that M2 was lower with a mean flux of $15 \mathrm{~cm} /$ day; M15 was much higher (360 
$\mathrm{cm} /$ day), and M6 was also higher (300 cm/day) (Table 7). As the radon measurements represent integrated values, the obtained agreement is reasonable.

This high variability was thus observed by both the radon monitoring and seepage meters in this dynamic environment around the submarine spring. The high variability in the radon record is a consequence of the radon rich groundwater source located close to the radon monitoring site, resulting in incomplete mixing between high-radon groundwater and low-radon seawater.

Using the same approach for the site C time series (Fig. 19b), we estimated a seepage rate through the sediments at $13-23 \mathrm{~cm} /$ day. This compares reasonably well to the manual seepage meter closest to this deployment (M9) that had a range of 3-22 cm/day, and a mean flux of $8 \mathrm{~cm} /$ day during the same period.

At site $\mathrm{D}$, we calculated a range in seepage of $14-25 \mathrm{~cm} /$ day based on the slope of the radon inventory versus time regression (Fig. 19c) and the estimated radon concentrations in the shallow groundwater. There were no manual seepage meters deployed at this site but the DSM seepage meter was operating nearby at the same time showing 5-28 cm/day (average $10 \mathrm{~cm} /$ day), which closely matches the radon rates. That was especially true for the last 3 data points measured by DSM (average $20 \mathrm{~cm} /$ day) that were the closest in timing to the radon measurements (Fig. 11d).

\subsubsection{Estimation of SGD fluxes from freshwater balance}

Using the hydrologic balance calculation of freshwater inputs and outputs, we estimated the freshwater SGD to the sea. Subtracting the groundwater pumping $\left(2.0 \times 10^{7} \mathrm{~m}^{3} / \mathrm{y}\right)$ from the estimated recharge $\left(9.5 \times 10^{7} \mathrm{~m}^{3} / \mathrm{y}\right)$ leaves an estimated freshwater discharge at the shoreline of $7.5 \times 10^{7} \mathrm{~m}^{3} / \mathrm{y}$. Dividing this discharge rate by the $8 \mathrm{~km}$ of shoreline yields an estimated discharge rate of $9400 \mathrm{~m}^{3} / \mathrm{y}$ per meter of shoreline $\left(26 \mathrm{~m}^{3} / \mathrm{m}\right.$ day). Assuming the discharge takes place over a $40 \mathrm{~m}$ zone perpendicular to the coast, a seepage rate of $0.65 \mathrm{~m} /$ day is calculated.

The reasonableness of the SGD value calculated was independently checked by performing a calculation using Darcy's Law, utilizing values for the Curepipe Aquifer. The hydraulic gradient $(\delta \mathrm{h} / \delta \mathrm{l})$ for the aquifer is $550 \mathrm{~m} / 17.5 \mathrm{~km}=0.031$. The average width (w) of the aquifer is $7 \mathrm{~km}$. If the majority of the flow $(\mathrm{Q})$ is expected to go through the more permeable Younger Series lava flows, then the transmissivity of those flows should be:

$\mathrm{T}=\mathrm{Q} / \mathrm{w} \delta \mathrm{h} / \delta \mathrm{l}=7.5 \times 10^{7} \mathrm{~m}^{3} \mathrm{y}^{-1} /[7000 \mathrm{~m} * 0.031]=3.5 \times 10^{5} \mathrm{~m}^{2} / \mathrm{y}=1.1 \times 10^{-2} \mathrm{~m}^{2} / \mathrm{s}$

This transmissivity is at the upper range of the transmissivities reported in Giorgi et al. (1999). Since a portion of the flow will undoubtedly be through the order-or-magnitude less-permeable Intermediate lava flows, the calculated transmissivity (and therefore, the estimated SGD) is within the range of reasonable values. In addition to flow through the Intermediate portion of the aquifer, it is likely that 
highly permeable lava tubes may account for a significant portion of the discharge, a component of SGD not taken into account by the above calculation. The observed submarine spring at Flic-en-Flac is most likely an example of enhanced discharge through a lava tube.

There are uncertainties in all of the values used in the above calculations. Acquisition of additional hydrogeologic data and more detailed data analysis could refine the calculation. The estimate is unlikely to increase by a factor of two, but could decrease by that much if evapotranspiration or groundwater pumping were significantly greater than estimated. Numerical simulation of the aquifer could potentially examine the effects of lava tubes on the flow regime and the resulting effects on the spatial distribution of freshwater SGD.

\subsection{Comparison of SGD fluxes obtained by different methods}

Measured specific seepage rates can be converted to average shoreline fluxes if one knows or can assume a width of the seepage face. Based on the seepage meter measurements, we estimate that the width of the seepage area in the lagoon is about 40 meters. Using this value, we have compared the shoreline SGD fluxes obtained from seepage meter measurements, water balance estimate and from three radon stations (Table 7). The water balance estimate $\left(26 \mathrm{~m}^{3} / \mathrm{m}\right.$ day) is quite close to the seepage meter value $\left(35 \mathrm{~m}^{3} / \mathrm{m}\right.$ day) measured with the northern seepage meters, not influenced by the submarine spring. If the submarine spring area is included in the assessment, then the estimated shoreline SGD flux increased to $220 \mathrm{~m}^{3} / \mathrm{m}$ day. The estimate using the radon inventory method has a wide range $\left(5-56 \mathrm{~m}^{3} / \mathrm{m}\right.$ day), reflecting different lagoon environments, including the impact of the submarine spring on the coastal SGD flux.

\section{Conclusions}

The SGD intercalibration experiment brought together a variety of methods for estimation of SGD fluxes, including salinity and radon surveys, manual and automated seepage meters, bulk sediment conductivity surveys, all providing evidence for significant discharge of groundwater into the Flic-en-Flac Lagoon on Mauritius Island. In addition groundwater and SGD waters were characterized by their stable and radioactive isotope signatures. Discharge showed large spatial and temporal heterogeneity likely caused by the presence of preferential groundwater flow conduits resulting from the coralline basement of the lagoon and lava tubes. This study represents the most comprehensive investigation carried out till now on the characterization of SGD using isotopic, geophysical, geobiochemical and hydrological methods. 
The main results obtained in this study may be summarized as follows:

(i) There were two modes of SGD observed in the lagoon. Terrestrially derived freshwater discharged in the vicinity of a large submarine spring with seepage rates as high as $490 \mathrm{~cm} /$ day. Flow was very spatially heterogeneous, with large fluctuations observed at sites situated only a few meters apart (from $0 \mathrm{~cm} /$ day to $360 \mathrm{~cm} /$ day). SGD fluxes calculated with the radon inventory method from radon time series measurements made $\sim 50 \mathrm{~m}$ from the spring site were between 65 and $140 \mathrm{~cm} /$ day. The seepage meter estimate is likely higher since it measured flux directly at the spring, while the radon method integrates the entire region around the spring.

(ii) Outside of the influence of the spring, SGD comprised re-circulated seawater, likely driven by a combination of tide and wave pumping. Indeed, most of the SGD samples collected in seepage chambers away from the spring had the same salinity as the lagoon. Temporal variability in SGD was also observed (from $50 \mathrm{~cm} /$ day to $370 \mathrm{~cm} /$ day) and appeared to fluctuate with the tide. The longest seepage meter deployment indicated that SGD peaked before low tide. However, some seepage meter time series measurements showed no relationship between discharge and tidal height, perhaps a result of the low rates and/or reversal of flow from discharge to infiltration (i.e. seawater recirculation). The mean seepage from all deployments was $10 \mathrm{~cm} /$ day. There was a reasonable agreement between nearshore SGD fluxes measured by seepage meters located at 28 sites ( 2 to $28 \mathrm{~cm} /$ day) and using the radon inventory method at two sites (away from the spring, 13 to $24 \mathrm{~cm} /$ day).

(iii) The integrated shoreline SGD fluxes as obtained from seepage meter measurements and the water balance estimate ( 35 and $26 \mathrm{~m}^{3} / \mathrm{m}$ day, respectively, excluding the effect of the submarine spring) are in very good agreement. Radon in situ measurements showed values between 5 and $56 \mathrm{~m}^{3} / \mathrm{m}$ day (including the impact of the submarine spring) for the investigated shoreline.

(iv) The isotopic composition of groundwater and surface water $\left(\delta^{2} \mathrm{H}, \delta^{18} \mathrm{O},{ }^{3} \mathrm{H}\right)$ clearly demonstrates end member mixing between fresh, terrestrially sourced groundwater and seawater, with water from wells, springs and seepage meters falling on the mixing line. The contribution of fresh, terrestrially sourced groundwater to SGD was calculated using a simple two end-members mixing model and varied from a few $\%$ to almost $100 \%$ depending on the location and the tidal phase. The rest in the SGD balance should be a mixture of groundwater and seawater re-circulating in the system. With increasing offshore distance this contribution became negligible. Mauritius Island represents the case with the largest contribution of fresh groundwater, when compared with other sites visited for SGD investigations by the IAEA/UNESCO group (e.g. east coast of Sicily, east coast of Brazil). 
(v) Analyses of radium isotopes in the submarine spring showed depleted values relative to offshore waters. This is due to a relatively low abundance of $U$ and $T h$ in the basalt that makes up the island. On the other hand, an enrichment of ${ }^{224} \mathrm{Ra}$ and ${ }^{223} \mathrm{Ra}$ relative to offshore waters was observed in the lagoon, indicating a regeneration and loss of ${ }^{224} \mathrm{Ra}$ and ${ }^{228} \mathrm{Th}$ in the fine-grained sediments.

(vi) High SGD rates result in high nutrient loading to the lagoon. The major inputs of dissolved nitrate and dissolved silicate in Flic-en-Flac area are from terrestrial sources including domestic effluents. High nutrient loading may lead to eutrophication with potentially harmful side affects for the local coral reef ecosystem. Dissolved nutrients may also undergo a series of transformation processes such as dilution and biological uptake in the lagoon.

The SGD intercomparison exercises were carried out in the framework IAEA-UNESCO collaboration to validate the various approaches used to measure SGD including manual and automated seepage meters, sediment bulk conductivity surveys, and salinity, radium and radon sampling. Each of these methods yields unique information about the character and magnitude of SGD. The results of the intercomparison studies have resulted a better understanding of groundwater-seawater interactions in coastal regions. Such information is an important pre-requisite for the protection management of coastal and freshwater resources.

\section{Acknowledgements}

The presented work was carried out in the framework of the UNESCO's International Hydrological Programme (IHP) and the Intergovernmental Oceanographic Commission (IOC) programs, and the IAEA's Isotope Hydrology Section in Vienna (coordinated by P.K. Aggarwal) and the IAEA's Marine Environment Laboratories in Monaco (coordinated by P.P. Povinec), in cooperation with laboratories in Brazil, India, Italy, Japan, Russia, Turkey, Slovenia and USA. The authors are grateful to colleagues from the University of Mauritius, the Mauritius Oceanographic Institute, and the Water Resources Unit for assistance during the sampling expedition, and for provision of information and documents useful for planning and executing the program of the expedition. The financial support provided by the IOC and IHP of UNESCO for travel arrangements, and by the IAEA's Marine Environment Laboratories for logistics is highly acknowledged. MAC and MEG were supported in part by the US National Science Foundation (OCE-0425061 and OCE-0751525). PPP acknowledges a support provided by the EU Research \& Development Operational Program funded by the ERDF (project No. 26240220004), and the Slovak Scientific Agency VEGA (grant No. 1/108/08). The International Atomic Energy Agency is grateful to the Government of the Principality of Monaco for support provided to its Marine Environment Laboratories.

\section{References}


Bokuniewicz, H.J., Rapaglia, J., Beck, A., 2006.. Submarine Groundwater Discharge (SGD) from a volcanic island: A case study in Mauritius Island. International Journal of Oceans and Oceanography: 1, 73-77.

Burnett, W.C., Kim, G., Lane-Smith, D., 2001. A continuous radon monitor for assessment of radon in coastal ocean waters. J. Radioanal. Nucl. Chem. 249, 167-172.

Burnett, W.C., Dulaiova, H., 2003. Estimating the dynamics of groundwater input into the coastal zone via continuous radon-222 measurements. J. Environ. Radioact. 69, 21-35.

Burnett, W.C., Povinec, P.P., Oberdorfer, J.A., Stieglitz, T., Rapaglia, J., Beck, A., Bokuniewicz, H., Kontar, E., Charette, M., Eagle Gonnea, M., Taniguchi, M., Ishitobi, T., Peterson, R., 2005. Submarine groundwater discharge assessment intercomparison experiment - Mauritius Island. Field Report to ICAM, IHP and IAEA.

Burnett, W.C., Aggarwal, P.K., Aureli, A., Bokuniewicz, H., Cable, J.E., Charette, M.A., Kontar, E., Krupa, S., Kulkarni, K.M., Loveless, A., Moore, W.S., Oberdorfer, J.A., Oliveira, J., Ozyurt, N., Povinec, P.P., Privitera, A.M.G., Rajar, R., Ramessur, R.T., Scholten, J., Stieglitz, T., Taniguchi, M., Turner, J.V., 2006. Quantifying submarine groundwater discharge in the coastal zone via multiple methods. Science of the Total Environment $367,498-543$.

Burnett, W.C., Dulaiova, H., 2006. Radon as a tracer of submarine groundwater discharge into a boat basin in Donnalucata, Sicily. Continental Shelf Research 26, 862-873.

Cable, J., Martin, J., Swarzenski, P., Lindenberg, M., Steward, J., 2004. Advection within shallow pore waters of a coastal lagoon. Ground Water 42, 1011-1020.

Clarke, W.B., Jenkins, W.J., Top, Z., 1976. Determination of tritium by mass-spectrometric measurements of ${ }^{3} \mathrm{He}$. International Journal of Radiation and Isotopes, 27, 512-522.

Coleman, M.L., Sheppard, T.J., Durham, J.J., Rouse, J.E., Moore, G.R., 1982. Reduction of water with zinc for hydrogen isotope analysis. Anal. Chem. 54, 993-995.

Craig, H., 1961. Isotopic variation in meteoric waters. Science 133, 1702-1703.

Dulaiova, H., Peterson, R., Burnett, W.C., 2005. A multi-detector continuous monitor for assessment of ${ }^{222}$ Rn in the coastal ocean. J. Radioanal. Nucl. Chem. 263, 361-365.

Epstein, S., Mayeda, T., 1953. Variation of $\mathrm{O}^{18}$ content of waters from natural sources. Geochim. Cosmochim. Acta 4, 213-224.

Garrison, G.H.; Glenn C.R., McMurtry, G.M., 2003. Measurement of submarine groundwater discharge in Kahana Bay, O’ahu, Hawaii. Limnology and Oceanography 48, 920-928.

Gendre, F., Beck, C., Ruch, P., Kübler, B., 1994. Human impacts on the coral ecosystems at Mauritius Island: coprostanol in surface sediments. Ecologae Geologicae Helvetiae 87, 357-367.

Giorgi, L., Borcheillini, S., Delucchi, L, 1999. Ile Maurice, Carte Geologique au 1:50 000, Schema hydrogeologique. Geolab, Mauritius.

Gonfiantini, R., 1978. Standards for stable isotope measurements in natural compounds. Nature 271, 534-536.

Groening, M, Auer, R, Brummer, D, Jaklitsch, M, Sambandam, C, Tanweer, A, Tatzber, H., 2009. Increasing the performance of tritium analysis by electrolytic enrichment. Isotopes in Environ. Health Studies 45, 118-125. 
Kim, G., Lee, K.K., Park, K.S., Hwang, D.W., Yang, H.S., 2002. Large submarine groundwater discharge (SGD) from a volcanic island. Geophys. Res. Letters 30, doi: 10.1029/2003GL018378.

Krupa, S.L., Belanger, T.V., Heck, H.H., Brok J.T., Jones, B.J., 1998. Krupaseep - the next generation seepage meter, J. Coastal Res. 25, 210-213.

Lee, D.R., 1977. A device for measuring seepage flux in lakes and estuaries. Limnology and Oceanography 22 , 140-147.

Livingston, H.D., Povinec, P.P., 2002. A millennium perspective on the contribution of global fallout radionuclides to ocean science. Health Phys. 82, 656-668.

McDougal, I., Chamalaun, F.G., 1969. Isotope dating and geomagnetic polarity studies on volcanic rocks from Mauritius, Indian Ocean. Geol. Soc. Am. Bull. 80, 1419:1442.

Ministry of Public Works, 2003. Hydrology Data Book (1995-1999). Water Resources Unit, Mauritius.

Moore, W.S., 1996. Large groundwater inputs to coastal waters revealed by Ra-226 enrichments. Nature 380, 612614.

Moore, W.S., 2000. Ages of continental shelf waters determined from ${ }^{223}$ Ra and ${ }^{224}$ Ra. J. Geophys. Res. 105, 2211722122.

Moore, W.S., 2006. Radium isotopes as tracers of submarine groundwater discharge in Sicily. Continental Shelf Research 26, 852-861.

Moore, W.S., Arnold, R., 1996. Measurement of ${ }^{223} \mathrm{Ra}$ and ${ }^{224} \mathrm{Ra}$ in coastal waters using a delayed coincidence counter. J. Geophys. Res. 101, 1321-1329.

Moore, W.S., Wilson, A.M., 2005. Advective flow through the upper continental shelf driven by storms, buoyancy and submarine discharge. Earth and Planetary Science Letters 235, 564-576.

Naidu, S, Aalbersberg, W.G.L., Brodie, J.E., 1991. Water quality studies on selected South Pacific lagoons. UNEP Regional seas reports and studies, No. 136. UNEP, New York, 99pp.

Osvath, I., Povinec, P.P., 2001. Seabed $\gamma$-ray spectrometry: applications at IAEA-MEL. J. Environ. Radioact. 53, 335-349.

Parsons, T.R, Maita, Y., Lalli, C.M., 1984. Chemical and biological methods for seawater analysis. Pergamon Press, New York, 173 pp.

Paytan, A., Shellenbarger, G.G., Street, J.H., Gonneea, M.E., Davis, K., Young, M.B., Moore, W.S., 2006. Submarine groundwater discharge: An important source of new inorganic nitrogen to coral reef ecosystems. Limnology and Oceanography 51, 343-348.

Povinec, P.P., Osvath, I., Baxter, M.S., 1996. Underwater gamma-spectrometry with HPGe and NaI (Tl) detectors. Appl. Radiat. Isot. 47, 1127-1133.

Povinec, P.P., La Rosa, J., Lee, S.-H., Mulsow, S., Osvath, I., Wyse, E., 2001. Recent developments in radiometric and mass spectrometry methods for marine radioactivity measurements. J. Radioanal. Nucl. Chem. 248, 713718. 
Povinec, P.P., Delfanti R, Gastaud J, La Rosa J, Morgenstern U, Oregioni B, Pham MK, Salvi S, Top Z., 2003. Anthropogenic radionuclides in the Indian Ocean surface waters - the Indian Ocean transect 1998. Deep-Sea Res. II 50, 2751-2760.

Povinec, P.P., Hirose, K., Honda, T., Ito, T., Scott, E.M., Togawa, O., 2004. Spatial distribution of ${ }^{3} \mathrm{H},{ }^{90} \mathrm{Sr},{ }^{137} \mathrm{Cs}$ and ${ }^{239,240} \mathrm{Pu}$ in surface waters of the Pacific and Indian Oceans - GLOMARD database. J. Environ. Radioact. 76, 113-137.

Povinec, P.P., Aggarwal, P.K., Aureli A., Burnett, W.C., Kontar, E.A., Kulkarni, K.M., Moore, W.S., Rajar, R., Taniguchi, M., Comanducci, J.-F., Cusimano, G., Dulaiova, H., Gatto, L., Hauser, S., Levy-Palomo, I., Ozorovich, Y.R., Privitera, A.M., Schiavo, M.A., 2006a. Characterisation of submarine ground water discharge offshore south-eastern Sicily - SGD Collaboration. J. Environ. Radioact. 89, 81-101.

Povinec, P.P., Comanducci, J.-F., Levy-Palomo, I., Oregioni, B., 2006b. Monitoring of submarine groundwater discharge along the Donnalucata coast in the south-eastern Sicily using underwater gamma-ray spectrometry of radon decay products. Continental Shelf Research 26, 874-884.

Povinec, P.P., Bokuniewicz, H., Burnett, W.C., Cable, J., Charette, M., Comanducci, J.-F., Kontar, E.A., Moore, W.S., Oberdorfer. J.A., Oliveira, J., Peterson, R., Stieglitz, T., Taniguchi, M., 2008a. Isotope tracing of submarine groundwater discharge offshore Ubatuba, Brazil: results of the IAEA-UNESCO SGD project. J. Environ. Radioact. 89, 81-101.

Povinec, P.P., Oliveira, J., Braga, E.S., Comanducci, J-F., Gastaud, J., Groening, M., Levy-Palomo, I., Morgenstern, U., Top, Z., 2008b. Isotopic, trace element and nutrient characterization of coastal waters from Ubatuba inner shelf area, southeastern Brazil. Estuarine, Coastal and Shelf Science 76, 522-542.

Povinec, P.P., Betti, M., Jull, A.J.T., Vojtyla, P., 2008c. New isotope technologies in environmental physics. Acta Phys. Slovaca 58, 1-154.

Proag, V., 1995. The Geology and Water Resource of Mauritius. Geography of Mauritius, 2. Mahatma Gandhi Institute, Reduit, Mauritius, pp. 939.

Ramessur, R.T., 2002. Anthropogenic-drive changes with focus on the coastal zone of Mauritius, south-western Indian Ocean. Regional Environmental Change, 3, 99-106.

Ramessur, R.T., Parry, S.J., Ramjeawon, T., 2001. The relationship of dissolved Pb to some dissolved trace metals $(\mathrm{Al}, \mathrm{Cr}, \mathrm{Mn}$ and $\mathrm{Zn}$ ) and to dissolved nitrate and phosphate in a freshwater aquatic system in Mauritius. Environment International 26, 223-230.

Schiavo, M.A., Hauser, S., Povinec, P.P., 2007. Isotope distribution of dissolved carbonate species in southeastern coastal aquifers of Sicily (Italy). Hydrological Processes 21, 2690-2697.

Schiavo M.A., Hauser, S., Povinec, P.P., 2009. Stable isotopes of water as a tool to study groundwater-seawater interactions in coastal south-eastern Sicily. Journal of Hydrology 364, 40- 49.

Sholkovitz, E.R., Herbold, C., Charette, M.A., 2003. An automated dye-dilution based seepage meter for the timeseries measurement of submarine groundwater discharge. Limnology and Oceanography Methods 1, 17-29.

Stieglitz, T., Ridd, P.V., Hollins, S., 2000. A small sensor for detecting animal burrows, and monitoring burrow water conductivity. Wetlands Ecology and Management 8, 1-7. 
Stieglitz, T., Taniguchi, M., Neylon, S., 2008. Spatial variability of submarine groundwater discharge, Ubatuba, Brazil. Estuarine, Coastal and Shelf Science 76, 493-500.

Stieglitz, T., Cook, P.G., Burnett, W.C., 2010. Inferring coastal processes from regional-scale mapping of ${ }^{222}$ Radon and salinity - Examples from the Great Barrier Reef, Australia. J. Environ. Radioact. 101, 544-552.

Swarzenski, P.W., Burnett, W.C., Weinstein, Y., Greenwood, W.J., Herut, B., Peterson, R., Dimova, N., 2006. Combined time-series resistivity and geochemical tracer techniques to examine submarine groundwater discharge at Dor Beach, Israel. Geophys. Res. Lett. 33, L24405. doi:10.1029/2006GL 028282.

Taniguchi, M., Iwakawa, H., 2001. Measurements of submarine groundwater discharge rates by a continuous heattype automated seepage meter in Osaka Bay, Japan. Journal of Groundwater Hydrology 43, 271-277.

Taniguchi M., Stieglitz, T., Ishitobi, T., 2007. Temporal variability of water quality of submarine groundwater discharge in Ubatuba, Brazil. Estuarine, Coastal and Shelf Science 76, 484-492.

Turner, J., Hardman, E., Klaus, R., Fagoonee, I., Daby, D., Baghooli, R., Persands, S., 2000. The reefs of Mauritius. In: D. Souter, D. Obdura and O. Lindén (Eds.), Coral reef degradation in the Indian Ocean: Status Report 2000, pp. 205.

Weinstein, Y., Less, G., Kafri, U., Herut, B., 2006. Submarine groundwater discharge in the Southeastern Mediterranean. In: Povinec, P.P., Sanchez-Cabeza, J.A. (Eds.). Radionuclides in the Environment. Elsevier, Amsterdam, p. 360-372. 
Table 1

Results for seawater samples collected in the lagoon and in the open ocean (see Fig. 2 for sample locations).

\begin{tabular}{|c|c|c|c|c|c|c|c|c|c|}
\hline $\begin{array}{c}\text { Sample } \\
\text { code }\end{array}$ & Location & Date/Time & $\begin{array}{c}\begin{array}{c}\text { Bottom depth } \\
\text { (m) }\end{array} \\
\text {. }\end{array}$ & $\begin{array}{c}\text { Temperature } \\
\left({ }^{\circ} \mathrm{C}\right)\end{array}$ & Salinity & $\begin{array}{c}\delta \mathrm{D} \\
(\%)\end{array}$ & $\begin{array}{l}\delta^{18} \mathrm{O} \\
(\%)\end{array}$ & $\begin{array}{c}{ }^{3} \mathrm{H} \\
(\mathrm{TU})\end{array}$ & Remarks \\
\hline \multicolumn{10}{|l|}{2005} \\
\hline SW-1 & $\begin{array}{l}2016440 \mathrm{~S} \\
5722000 \mathrm{E}\end{array}$ & 20/9:15 & 6 & 28.0 & 32.7 & 1.6 & 0.2 & & $\begin{array}{c}\text { Submarine spring, } \\
\text { surface }\end{array}$ \\
\hline & 2016440 & & & & & -0.3 & -0.1 & & Submarine spring, \\
\hline SW-2 & 5722000 & 20/11:30 & 6 & 28.6 & 29.8 & & & & half-depth \\
\hline & 2016440 & & & & & -13.7 & -2.5 & & Submarine spring, \\
\hline SW-3 & 5722000 & 21/12:15 & 6 & 28.5 & 6.0 & & & & bottom \\
\hline & 2016440 & & & & & -13.8 & -2.8 & $0.87 \pm 0.02$ & Submarine spring, \\
\hline SW-4 & 5722000 & 21/13:30 & 6 & 28.5 & 4.0 & & & & bottom \\
\hline & 2016261 & & & & & 1.8 & 0.3 & & Port, \\
\hline SW-5 & 5722085 & 21/14:10 & 1 & 28.3 & 32.6 & & & & surface \\
\hline SW-6 & $\begin{array}{l}2015530 \\
5721388\end{array}$ & $22 / 10: 30$ & $>59$ & 28.56 & 34.59 & 2.4 & -0.5 & & $\begin{array}{l}\text { Open ocean } \\
(1 \mathrm{~km}) \\
\text { surface }\end{array}$ \\
\hline SW-7 & $\begin{array}{l}2015407 \\
5719445\end{array}$ & $22 / 11: 50$ & $>43$ & 28.56 & 34.61 & & & & $\begin{array}{l}\text { Open ocean } \\
\quad(1 \mathrm{~km}), \\
\text { surface }\end{array}$ \\
\hline SW-8 & $\begin{array}{l}2015533 \\
5720232\end{array}$ & $22 / 11: 20$ & $>48$ & 28.60 & 34.56 & & & & $\begin{array}{l}\text { Open ocean } \\
(2 \mathrm{~km}) \\
\text { surface }\end{array}$ \\
\hline SW-9 & $\begin{array}{l}2016036 \\
5721426\end{array}$ & $22 / 11: 50$ & $>48$ & 28.54 & 34.66 & 4.3 & 0.6 & $0.88 \pm 0.02$ & $\begin{array}{l}\text { Open ocean } \\
(3 \mathrm{~km}), \\
\text { surface }\end{array}$ \\
\hline SW-10 & $\begin{array}{l}2016121 \\
5722141\end{array}$ & 22/12:05 & 7.5 & 28.55 & 34.52 & 3.5 & 0.5 & $0.80 \pm 0.02$ & $\begin{array}{l}\text { Open ocean } \\
(1 \mathrm{~km}), \\
\text { surface }\end{array}$ \\
\hline SW-11 & $\begin{array}{l}2015220 \\
5722293\end{array}$ & $22 / 12: 25$ & 31 & 28.62 & 34.56 & 3.4 & 0.4 & & $\begin{array}{l}\text { Open ocean } \\
\quad(1 \mathrm{~km}) \\
\text { surface }\end{array}$ \\
\hline SW-12 & $\begin{array}{l}2010219 \\
5726309\end{array}$ & 25/11:00 & 1.5 & 28.6 & 30.5 & 0.9 & 0.1 & $0.98 \pm 0.02$ & $\begin{array}{l}\text { Submarine spring } \\
\text { at Pointe aux } \\
\text { Sables }\end{array}$ \\
\hline 2004 & & & & & & & & & \\
\hline SW-15 & Lagoon & & & & 32.9 & 3.4 & 0.42 & & Lagoon, Klondike \\
\hline SW-16 & Lagoon & & & & 33.0 & 4.4 & 0.5 & & $\begin{array}{l}\text { Lagoon, Dirty } \\
\text { Cove }\end{array}$ \\
\hline SW-17 & Lagoon & & & & 33.7 & 2.5 & 0.34 & & $\begin{array}{l}\text { Lagoon, south of } \\
\text { the South beach }\end{array}$ \\
\hline SW-17 & Lagoon & & & & 32.5 & 2.7 & 0.36 & & Lagoon, Port \\
\hline SW-17 & Lagoon & & & & 32.1 & -0.01 & 0.87 & & $\begin{array}{l}\text { Lagoon, South } \\
\text { beach }\end{array}$ \\
\hline
\end{tabular}

Table 2 
Results for water samples collected from seepage chambers located alongside of the coast at Flic-en-Flac (see Fig. 2 for sample locations).

\begin{tabular}{|c|c|c|c|c|c|c|c|c|}
\hline $\begin{array}{l}\text { Sample } \\
\text { number }\end{array}$ & Chamber & Date/Time & Temperature $\left({ }^{\circ} \mathrm{C}\right)$ & $\begin{array}{c}\text { Conductivity } \\
(\mathrm{mS} / \mathrm{cm})\end{array}$ & Salinity & $\begin{array}{l}\delta^{2} H^{*} \\
(\%)\end{array}$ & $\begin{array}{l}\delta^{18} \mathrm{O}^{*} \\
(\%)\end{array}$ & $\begin{array}{c}{ }^{3} \mathbf{H} \\
(\mathrm{TU})\end{array}$ \\
\hline SM-1 & A-1 & $19 / 17.00$ & 28.1 & 14.35 & 8.4 & -12.3 & -2.3 & $1.10 \pm 0.15$ \\
\hline SM-2 & M-2 & $19 / 18.15$ & 28.0 & 51.8 & 34.1 & 3.7 & 0.4 & \\
\hline \multirow[t]{5}{*}{ SM-3 } & M-1 & $20 / 9.45$ & 28.0 & 14.52 & 8.6 & -10.8 & -2.3 & $1.02 \pm 0.25$ \\
\hline & M-1 & 10.00 & 28.9 & 42.7 & 27.2 & -11.5 & -2.7 & $0.94 \pm 0.20$ \\
\hline & M-1 & 11.30 & 28.9 & 30.9 & 19.2 & & & \\
\hline & M-1 & 11.50 & 28.9 & 23.4 & 14.1 & & & \\
\hline & M-1 & 15.10 & 29.0 & 6.52 & 3.6 & & & \\
\hline \multirow[t]{4}{*}{ SM-9 } & M-1 & $20 / 15.40$ & 29.2 & 6.51 & 3.6 & -15.5 & -2.8 & $0.65 \pm 0.02$ \\
\hline & M-1 & 16.00 & 29.7 & 5.95 & 3.2 & & & \\
\hline & M-2 & $20 / 10.30$ & 28.7 & 50.9 & 33.4 & & & \\
\hline & M-2 & 11.30 & 28.7 & 50.9 & 33.4 & & & \\
\hline \multirow[t]{5}{*}{ SM-10 } & $\mathrm{M}-2$ & 16.30 & 30.6 & 50.5 & 33.0 & 4.2 & 0.4 & \\
\hline & M-3 & $20 / 10.00$ & 28.8 & 28.4 & 17.6 & & & \\
\hline & M-3 & 11.00 & 28.5 & 28.3 & 17.4 & & & \\
\hline & M-3 & 12.00 & 28.5 & 28.3 & 17.3 & & & \\
\hline & M-3 & 13.00 & 28.5 & 28.3 & 17.3 & & & \\
\hline \multirow[t]{2}{*}{ SM-8 } & M-3 & 20/15:35 & 29.4 & 30.7 & 19.1 & -5.9 & -1.2 & $0.93 \pm 0.02$ \\
\hline & M-3 & $16: 10$ & 29.9 & 30.7 & 19.0 & & & \\
\hline \multirow[t]{5}{*}{ SM-4 } & M-6 & $20 / 11.40$ & 29.2 & 12.28 & 7.0 & -11.9 & -2.5 & $0.98 \pm 0.02$ \\
\hline & M-6 & 15.25 & 29.2 & 7.33 & 4.1 & & & \\
\hline & M-6 & 15.55 & 30.1 & 7.33 & 4.1 & & & \\
\hline & M-6 & 16.15 & 30.5 & 9.00 & 5.1 & & & \\
\hline & M-6 & $22 / 12: 15$ & 30.2 & 8.23 & 5.8 & -12.7 & -2.5 & $1.00 \pm 0.15$ \\
\hline SM-5 & M-7 & $20 / 11.45$ & 28.8 & 51.1 & 33.6 & 2.9 & 0.6 & \\
\hline \multirow[t]{2}{*}{ SM-6 } & M-8 & $20 / 11.55$ & 29.2 & 50.4 & 33.0 & 2.3 & 0.4 & \\
\hline & M-8 & 12.30 & 29.2 & 50.4 & 33.0 & & & \\
\hline \multirow[t]{2}{*}{ SM-7 } & M-4 & 20/15.15 & 29.7 & 51.9 & $34 . .3$ & 5.1 & 0.4 & \\
\hline & M-4 & 16.20 & 29.9 & 51.5 & 33.8 & & & \\
\hline \multirow[t]{2}{*}{ SM-7b } & M-5 & $20 / 15.15$ & 28.9 & 51.3 & 33.7 & & & \\
\hline & M-5 & 16.20 & 29.7 & 50.9 & 33.6 & & & \\
\hline SM-11 & M-1 & $22 /$ noon & 28.9 & 7.16 & 3.9 & & & \\
\hline SM-12 & M-4 & $22 /$ noon & 29.7 & 52.4 & 34.3 & & & \\
\hline SM-13 & M-6 & $22 /$ noon & 29.2 & 7.91 & 4.4 & & & \\
\hline SM-14 & M-13 & $22 /$ noon & 28.8 & 23.4 & 14.1 & -8.1 & -1.7 & \\
\hline SM-15 & M-15 & $22 /$ noon & 28.5 & 8.26 & 4.6 & -14.3 & -2.7 & $0.89 \pm 0.02$ \\
\hline SM-16 & M-21 & $22 /$ noon & 28.8 & 48.6 & $31 . .5$ & -1.3 & -0.2 & \\
\hline SM-17 & M-26 & $22 /$ noon & 28.8 & 47.6 & 30.7 & -2.9 & -0.5 & \\
\hline SM-18 & B-1 & $22 /$ noon & 29.2 & 49.8 & 32.5 & 1.1 & 0.1 & \\
\hline SM-19 & B-2 & $22 /$ noon & 29.9 & 51.5 & 33.5 & 2.7 & 0.3 & \\
\hline SM-20 & B-3 & $22 /$ noon & 28.8 & 51.7 & 33.9 & 1.7 & 0.3 & \\
\hline SM-21 & B-4 & $22 /$ noon & 28.9 & 52.1 & 34.0 & 1.2 & 0.5 & \\
\hline SM-22 & B-5 & $22 /$ noon & 29.2 & 52.3 & 34.2 & 0.4 & 0.5 & \\
\hline
\end{tabular}

Table 3

Results for water samples collected from the boreholes wells drilled in front of the submarine spring (see Fig. 2 for sample locations). 


\begin{tabular}{|c|c|c|c|c|c|c|c|c|c|}
\hline $\begin{array}{l}\text { Sample } \\
\text { number }\end{array}$ & Location & Date/Time & Temperature $\left({ }^{\circ} \mathrm{C}\right)$ & $\begin{array}{c}\begin{array}{c}\text { Conductivity } \\
(\mathrm{mS} / \mathrm{cm})\end{array} \\
\end{array}$ & Salinity & $\begin{array}{c}\delta \mathrm{D} \\
(\%)\end{array}$ & $\begin{array}{l}\delta^{18} \mathrm{O} \\
(\%) \\
\end{array}$ & $\begin{array}{c}{ }^{3} \mathbf{H} \\
(\mathrm{TU}) \\
\end{array}$ & Remarks \\
\hline BH-1/1 & BH-1 & 24/11:00 & 27.1 & 11.37 & 5.9 & -17.3 & -3.1 & $0.98 \pm 0.02$ & $\begin{array}{l}\text { Medium } \\
\text { tide/storm }\end{array}$ \\
\hline BH- $1 / 2$ & BH-1 & 25/12:10 & 28.5 & 16.63 & 9.9 & -15.5 & -2.7 & $0.69 \pm 0.02$ & High tide/storm \\
\hline BH-4/1 & BH-4 & $24 / 11: 00$ & 28.1 & 21.5 & 13.5 & -10.6 & -1.9 & $0.82 \pm 0.02$ & $\begin{array}{l}\text { Medium } \\
\text { tide/storm }\end{array}$ \\
\hline BH- $4 / 2$ & BH-4 & 25/12:30 & 28.0 & 30.6 & 19.1 & & & & High tide/storm \\
\hline
\end{tabular}




\section{Table 4}

Groundwater and rainwater samples collected from wells and surface springs on land in the Flic en Flac area. All samples were collected on March 23, 2005 (see

Fig. 2 for sample locations).

\begin{tabular}{|c|c|c|c|c|c|c|c|c|}
\hline $\begin{array}{l}\text { Sample } \\
\text { number }\end{array}$ & Location & Site & $\begin{array}{c}\text { Temperature } \\
\left({ }^{\circ} \mathrm{C}\right)\end{array}$ & $\begin{array}{c}\text { Conductivity } \\
(\mu \mathrm{S} / \mathrm{cm})\end{array}$ & $\begin{array}{c}\delta \mathrm{D} \\
(\%)\end{array}$ & $\begin{array}{l}\delta^{18} \mathrm{O} \\
(\%)\end{array}$ & $\begin{array}{c}{ }^{3} \mathbf{H} \\
(\mathbf{T U})\end{array}$ & Remarks \\
\hline \multicolumn{9}{|l|}{2005} \\
\hline GW-1 & $\begin{array}{c}2016328 \mathrm{~S} 57 \\
22085 \mathrm{E}\end{array}$ & Hotel Villa Caroline & 26.8 & 581 & -19.0 & -3.3 & $0.71 \pm 0.02$ & $\begin{array}{l}\text { Private well, } \sim 100 \mathrm{~m} \text { from the } \\
\text { sea, water level } 7 \mathrm{~m} \text { below the } \\
\text { surface, water height } 2 \mathrm{~m}, \sim 30 \\
\mathrm{~L} / \mathrm{min}\end{array}$ \\
\hline GW-2 & $\begin{array}{c}20183755722 \\
066\end{array}$ & Hotel Sofitel & 28.1 & 1168 & -21.0 & -3.6 & $1.13 \pm 0.02$ & $\begin{array}{l}\text { Private well, } \sim 200 \mathrm{~m} \text { from the } \\
\text { sea, } 25 \mathrm{~m} \text { deep, water height } 3 \\
\mathrm{~m}, \sim 100 \mathrm{~m}^{3} / \mathrm{day}\end{array}$ \\
\hline GW-3 & $\begin{array}{c}20174095722 \\
247\end{array}$ & Woolmar-2, well 66B & 25.4 & 425 & -14.8 & -2.9 & $0.81 \pm 0.15$ & $\begin{array}{l}\text { Observational well located in the } \\
\text { field, } 6 \mathrm{~m} \text { deep }\end{array}$ \\
\hline GW-5 & $\begin{array}{c}20162575723 \\
118\end{array}$ & Anna, well No. 840 & 24.8 & 408 & -17.0 & -3.1 & $1.15 \pm 0.15$ & $\begin{array}{l}\text { Agricultural well, } \sim 2 \mathrm{~km} \text { from } \\
\text { the sea, } 48 \mathrm{~m} \text { deep, } 8 \mathrm{~m} \text { water } \\
\text { level (variable), } 400 \mathrm{~m}^{3} / \mathrm{day}\end{array}$ \\
\hline GW-6 & $\begin{array}{c}20165255724 \\
115\end{array}$ & Well No. 26 B & 24.2 & 424 & -17.1 & -3.1 & $1.10 \pm 0.15$ & $\begin{array}{l}\text { Big circular reservoir, the } \\
\text { sample collected from a well } \\
\text { behind, } 1500 \mathrm{~m}^{3} / \text { day }\end{array}$ \\
\hline GW-7 & $\begin{array}{c}20163465724 \\
178\end{array}$ & Well No. 419 & 24.3 & 347 & -17.5 & -3.1 & $0.62 \pm 0.15$ & $\begin{array}{l}\text { Well situated close to the tower, } \\
\qquad 1300 \mathrm{~m}^{3} / \text { day }\end{array}$ \\
\hline GW-8 & $\begin{array}{c}20185035724 \\
130\end{array}$ & Well No. 711b & 26.5 & 1504 & -21.6 & -3.6 & $0.300 \pm 0.006$ & $\begin{array}{l}\text { Well close to the main road, } 34 \\
\mathrm{~m} \text { depth, water level } 0.4 \mathrm{~m}\end{array}$ \\
\hline S-1 & $\begin{array}{c}20160185723 \\
085\end{array}$ & Anna spring & 24.5 & 392 & -18.3 & -3.2 & $1.07 \pm 0.02$ & $\begin{array}{l}\text { Surface spring }\left(\sim 4 \mathrm{~m}^{3}\right) \text { close to } \\
\text { the observational well, water } \\
\text { height } 1 \mathrm{~m}, 62 \mathrm{~m} \text { above sea level }\end{array}$ \\
\hline RW-1 & & Klondike hotel & 32.5 & 5.8 & $\begin{array}{l}-35.6 \\
-13.2\end{array}$ & $\begin{array}{l}-5.3 \\
-2.84\end{array}$ & $1.55 \pm 0.03$ & Rain water, site D \\
\hline \multicolumn{9}{|l|}{2004} \\
\hline RI-1 & & South beach & & & -8.0 & -2.40 & & River water, site C \\
\hline $\mathrm{S}-2$ & Inland & Anna spring & & & -16.6 & -3.11 & $1.10 \pm 0.02$ & Surface spring, inland \\
\hline S-3 & Beach & Spring & & & -15.5 & -3.08 & & $\begin{array}{l}\text { Spring, south of the South beach, } \\
\text { site C }\end{array}$ \\
\hline S-4 & Beach & Spring & & & -9.8 & -2.67 & & Spring, Klondike Cove, site D \\
\hline S-5 & Beach & Spring & & & -12.9 & -2.66 & & Spring,, site B \\
\hline S-6 & Beach & Spring & & & -15.2 & -3.06 & & Spring, site B \\
\hline SRE-1 & Inland & Reservoir & & & -8.2 & -2.43 & & Inland water reservoir \\
\hline
\end{tabular}


Table 5

Radium isotope results in Mauritius samples (all activities are in $\mathrm{mBq} / \mathrm{L}$ ) (see Fig. 2 and Tables 3 and 4 for sample description and location).

\begin{tabular}{|c|c|c|c|c|c|c|c|c|}
\hline Sample & Date/Time & $\begin{array}{l}\text { Volume } \\
\text { (L) }\end{array}$ & Salinity & ${ }^{226} \mathrm{Ra}$ & ${ }^{228} \mathrm{Ra}$ & $\mathrm{ex}^{224} \mathrm{Ra}$ & ${ }^{223} \mathrm{Ra}$ & ${ }^{228} \mathrm{Th}$ \\
\hline $\begin{array}{c}\text { Spring-1 } \\
\text { (site A) }\end{array}$ & $21 / 15: 00$ & 15 & 6.1 & 0.48 & $\mathrm{bd}$ & 1.15 & 0.08 & 0.14 \\
\hline $\begin{array}{l}\text { Spring-2a } \\
\text { (site A) }\end{array}$ & $21 / 15: 20$ & 15 & & & & 0.52 & 0.14 & 0.20 \\
\hline $\begin{array}{l}\text { Spring-2b } \\
\text { (site A) }\end{array}$ & $21 / 15: 45$ & 15 & 6.89 & bd & bd & 0.42 & 0.10 & 0.13 \\
\hline $\begin{array}{l}\text { Spring - } \\
\text { combined } \\
(1+2 a+2 b)\end{array}$ & $21 / 15: 20$ & 45 & 6.5 & 0.90 & 3.34 & 0.70 & 0.0 .11 & 0.16 \\
\hline $\begin{array}{l}\text { Spring-3 } \\
\text { (site A) }\end{array}$ & $23 / 16: 30$ & 20 & 3.49 & 0.56 & bd & bd 0.51 & 0.0 .13 & 0.08 \\
\hline SW-1 & $21 / 14: 30$ & 75 & 32.7 & 1.56 & 0.80 & 3.30 & 0.09 & 0.10 \\
\hline SW-5 & 21/16:00 & 100 & 32.6 & 1.31 & 0.64 & 2.57 & 0.0 .10 & 0.08 \\
\hline SW-6 & $22 / 10: 30$ & 100 & 34.59 & 1.28 & 0.51 & 0.38 & 0.01 & 0.10 \\
\hline SW-7 & $22 / 11: 50$ & 100 & 34.61 & 1.40 & 0.47 & 0.25 & 0.01 & 0.09 \\
\hline SW-8 & $22 / 11: 20$ & 100 & 34.56 & 1.47 & 0.75 & 0.35 & 0.01 & 0.07 \\
\hline SW-9 & $22 / 10: 55$ & 100 & 34.66 & 1.35 & 0.65 & 0.25 & 0.01 & 0.11 \\
\hline SW-10 & $22 / 12: 05$ & 100 & 34.52 & 1.38 & 0.68 & & 0.01 & 0.08 \\
\hline SW-11 & $22 / 12: 25$ & 100 & 34.56 & 1.39 & 0.66 & 0.28 & 0.02 & 0.10 \\
\hline $\begin{array}{c}\mathrm{GW} \text { pit } 0.8 \mathrm{~m} \\
\text { (site } \mathrm{A})\end{array}$ & $23 / 11: 30$ & 10 & 4.24 & 0.53 & $\mathrm{bd}$ & 0.60 & 0.06 & 0.11 \\
\hline $\begin{array}{c}\text { GW pit } 1.8 \mathrm{~m} \\
\text { (site } \mathrm{A})\end{array}$ & $23 / 13: 15$ & 10 & 9.48 & 1.12 & $\mathrm{bd}$ & 0.79 & 0.18 & 0.08 \\
\hline $\begin{array}{c}\text { GW pit } 1.2 \mathrm{~m} \\
\text { (site }(\mathrm{A})\end{array}$ & $23 / 16: 55$ & 10 & 19.02 & 1.77 & $\mathrm{bd}$ & 0.90 & 0.36 & 0.08 \\
\hline GW-2 & 23/12:00 & 15 & 0 & & & bd & 0.12 & bd \\
\hline GW-3 & 23/12:00 & 15 & 0 & & & bd & bd & bd \\
\hline
\end{tabular}

bd = below detection

typical uncertainties are below $10 \%$ (at 1 sigma) 


\section{Table 6}

Concentrations of nutrients in waters at Flic-en-Flac region* (see Fig. 2 and Tables 1-4 for sample description and location).

\begin{tabular}{|c|c|c|c|c|c|c|}
\hline Sample & $\begin{array}{c}\text { Phosphate } \\
(\mu \mathrm{g} / \mathrm{L})\end{array}$ & $\begin{array}{l}\text { Nitrate } \\
(\mu \mathrm{g} / \mathrm{L})\end{array}$ & $\begin{array}{l}\text { Nitrite } \\
(\mu \mathrm{g} / \mathrm{L})\end{array}$ & $\begin{array}{c}\text { Silicate } \\
(\mu \mathrm{g} / \mathrm{L})\end{array}$ & $\begin{array}{c}\begin{array}{c}\text { Potassium } \\
(\mu \mathrm{g} / \mathrm{L})\end{array} \\
\end{array}$ & $\begin{array}{c}\text { Calcium } \\
(\mu \mathrm{g} / \mathrm{L})\end{array}$ \\
\hline GW-1 & 95.2 & 2380 & $<10$ & 9820 & 0.6 & 26.7 \\
\hline GW-2 & 43.5 & 3190 & $<10$ & 9490 & 7.7 & 49.4 \\
\hline GW-3 & 40.2 & 5480 & $<10$ & 13430 & 0.00 & 9.8 \\
\hline GW-4 & $<10$ & 7490 & $<10$ & 8711 & 0.00 & 8.1 \\
\hline GW-5 & $<10$ & 5480 & $<10$ & 9040 & 0.00 & 7.71 \\
\hline GW-6 & 61.2 & 8230 & $<10$ & 8540 & 0.00 & 17.7 \\
\hline GW-7 & 37.4 & 393 & $<10$ & 10270 & 0.00 & 11.5 \\
\hline SM-3 & 21.7 & 3440 & 82.9 & 3030 & 35.2 & 81.1 \\
\hline SM-7 & 51.7 & 26.0 & $<10$ & 298.7 & 121.7 & 380 \\
\hline SM-7b & 36.0 & 26.0 & $<10$ & 248.7 & 131.5 & 550 \\
\hline SM-13 & 61.7 & 3510 & 17.6 & 4550 & 39.9 & 97.6 \\
\hline SM-14 & 21.7 & 1510 & 48.3 & 3150 & 77.8 & 184.0 \\
\hline SM-15 & 18.8 & 1450 & $<10$ & 2140 & 50.6 & 106.2 \\
\hline SW-1 & $<10$ & $<10$ & $<10$ & 69.8 & 137.6 & 680 \\
\hline SW-2 & $<10$ & 171 & $<10$ & 280.9 & 138.5 & 514 \\
\hline SW-3 & $<10$ & 179 & $<10$ & 243.1 & 130.7 & 472 \\
\hline SW-4 & $<10$ & 166 & $<10$ & 237.6 & 128.4 & 586 \\
\hline SW-5 & $<10$ & 373 & $<10$ & 476.4 & 131.0 & 589 \\
\hline SW-6 & $<10$ & 323 & $<10$ & 432.0 & 128.4 & 349 \\
\hline SW-7 & $<10$ & $<10$ & $<10$ & 154.2 & 123.9 & 555 \\
\hline SW-8 & $<10$ & $<10$ & $<10$ & 643 & 117.6 & 514 \\
\hline SW-9 & $<10$ & $<10$ & $<10$ & 160.9 & 132.8 & 927 \\
\hline SM-18 & 81.71 & $<10$ & $<10$ & 964 & 123.7 & 605 \\
\hline SM-19 & 46.00 & $<10$ & $<10$ & 655 & 131.0 & 528 \\
\hline SM-20 & 127.43 & $<10$ & $<10$ & 574 & 128.1 & 532 \\
\hline SM-21 & 36.00 & $<10$ & $<10$ & 393 & 130.1 & 346 \\
\hline SM-22 & 14.57 & $<10$ & $<10$ & 330 & 130.7 & 569 \\
\hline BH $4 / 1$ & 70.17 & 1330 & $<10$ & 1550 & 106.3 & 230.5 \\
\hline BH $1 / 2$ & 160.17 & 1330 & $<10$ & 1680 & 32.1 & 164.4 \\
\hline $\mathrm{S} 1$ & 40.17 & 984 & $<10$ & 960 & 121.4 & 500 \\
\hline SW-5 km & $<10$ & 79.6 & $<10$ & 25900 & 311.4 & 10.6 \\
\hline SW-10 km & $<10$ & 213 & $<10$ & 16900 & 295.6 & 11.8 \\
\hline SW-15 km & $<10$ & 190 & $<10$ & 24900 & 295.6 & 11.2 \\
\hline
\end{tabular}

* The precision of measurements $(1 \sigma)$ was $\pm 1 \%$. 
Table 7

Estimated SGD fluxes in the Flic-en-Flac Lagoon

\begin{tabular}{|c|c|c|c|c|c|}
\hline \multirow[t]{2}{*}{ Site } & \multicolumn{2}{|c|}{$\begin{array}{l}\text { SGD fluxes } \\
\text { (cm/day) }\end{array}$} & \multicolumn{3}{|c|}{$\begin{array}{l}\text { SGD fluxes per unit width of shoreline basin of } 40 \mathrm{~m} \text { wide } \\
\qquad\left(\mathrm{m}^{3} / \mathrm{m} \text { day }\right)\end{array}$} \\
\hline & Seepage meters & Radon & Seepage meters & Radon & Water balance \\
\hline Submarine spring & $\begin{array}{l}\text { M2: 1-30 } \\
\text { M15: 360 } \\
\text { M6: 110-490 }\end{array}$ & $\begin{array}{l}80-130 \\
65-110 \\
80-140 \\
\end{array}$ & $0.5-120$ & $26-56$ & \\
\hline Klondike site & WHOI: 5-28 & $14-24$ & $2-11$ & $6-10$ & \\
\hline South beach & M9: 3-22 & $13-23$ & $1-9$ & $5-9$ & \\
\hline $\begin{array}{l}\text { Shore parallel transect (without } \\
\text { spring) }\end{array}$ & & & 35 & & 26 \\
\hline $\begin{array}{l}\text { Shore parallel transect } \\
\text { (including spring) }\end{array}$ & & & 220 & & \\
\hline
\end{tabular}




\section{Figure captions}

Fig. 1. Mauritius Island in the Indian Ocean. Sampling and in situ measurements were carried out on the western coast around Flic-en-Flac town.

Fig. 2. View of the groundwater sampling sites (after Google). Positions of seepage meters (M1-M26, B1-B5, DSM - dye-dilution seepage meter indicated by "+"), boreholes (BH1-BH5) alongside of the beach at Flic-en-Flac, and average SGD flow rates are also shown.

Fig. 3. Positions of boreholes in front of the submarine spring (surrounded by buoys). A boat for ${ }^{222} \mathrm{Rn}$ time series measurements is seen as well.

Fig. 4. Wind speed, air temperature, and barometric pressure during the intercomparison experiment. The labeled horizontal lines refer to deployment of the continuous radon monitor at different sires.

Fig. 5. Salinity and temperature profiles in the open sea (for station positions see Table 1).

Fig. 6. Near-shore surface water salinity survey carried out on different days. Transect on 18 March was recorded just after some minor rainfall, on 20 March after a $24 \mathrm{~h}$ period with no significant rain, and on 24 March during the tropical cyclone Hennie.

Fig. 7. Inverse correlation between salinity and mean SGD flow rates measured with 28 seepage chambers.

Fig. 8. Mean SGD flow rates measured with seepage chambers located in three different shore normal transects (A, B, C - see Fig. 2). Measurements within each transect were taken simultaneously. Please note the different scales due to major differences in the magnitude of flow rates and distance from shore.

Fig. 9. Mean SGD flow rates versus distance from spring taken from devices located immediately offshore in a shore parallel transect.

Fig. 10. SGD vs. tidal level at three devices along a shore normal transect in the vicinity of the submarine spring (measured on 20 March 2005 ).

Fig. 11. Temporal seepage rate investigations carried out using the dye-dilution seepage meter. (a) Results from deployment at site B (smooth line - salinity record; . (b) Results from the submarine spring deployment (site A), northern edge. (c) Results from station M9 deployment (site C). (d) Results from Klondike Hotel beach deployment (site D). On March 24 at 14:00 (local time) the dye-dilution spectrophotometer was removed due to the Hennie storm (but the chamber and CTDs were left in place).

Fig. 12. Plot of $\delta \mathrm{D}$ vs. $\delta^{18} \mathrm{O}$ for groundwater, seawater and their mixtures. Seawater and SGD samples are highly enriched in $\delta^{18} \mathrm{O}$, and they are situated well below the Global Meteoric Water Line (GMWL)

Fig. 13. Plot of ${ }^{3} \mathrm{H}$ vs. $\delta^{18} \mathrm{O}$ for groundwater and seawater samples and their mixtures (RW - rain water; $\mathrm{W}$ - groundwater wells; $\mathrm{BH}-$ borehole wells; SM - seepage meters; SGD - submarine groundwater discharge; SW - seawater). The large boxes and the circle indicate possible groundwater and seawater end-members.

Fig. 14. Radon survey on March 20, 2005, at the Flic-en-Flac Lagoon.

Fig. 15. Shore-normal transect of bulk ground conductivity at Site B at different tidal water levels. The beach slope as estimated from water level measurements at each station is shown, and the water level is marked with a blue line. The color bar indicates the range of the bulk ground conductivity in $\mathrm{mS} / \mathrm{cm}$.

Fig. 16. Bulk ground conductivity of the near-surface sediment around the submarine spring (site A). The main spring and locations of seepage meters are indicated with an orange triangle and with circles respectively ( $\mathrm{M}$ - manual meters; WH - Woods Hole dye dilution meter; A4 automated meter)

Fig. 17. Profiles of bulk ground conductivity in the upper $100 \mathrm{~cm}$ of the sediment. The arrows represent mean SGD measurements taken from manual seepage meters. A is the alongshore profile using the spring as the reference point. $\mathrm{B}$ is the shore normal profile taken $10 \mathrm{~m}$ south of the spring.

Fig. 18. Shore-normal bulk ground conductivity transect at low and high tide (location marked with a dashed line in Fig. 15). Arrows mark the locations of the manual seepage meters M5, M6 and M13 respectively. The length of the arrows is proportional to the average flux of SGD into each of these seepage meters, and the average salinity of the SGD is given in brackets with the name of each meter. The high tide transect is short, because the instrument was damaged beyond repair during recording.

Fig. 19. Radon inventory time-series at the submarine spring (a, site A), at the South beach (b, site C) and in front of the Klondike hotel (c, site D). Filled circles indicate the points used for regressions. Start of measurements: (a) March 22, 2005 at 12:11; (b) March 23, 2005 at 9:00; (c) March 24, 2005 at 9:00. 



Fig. 1 


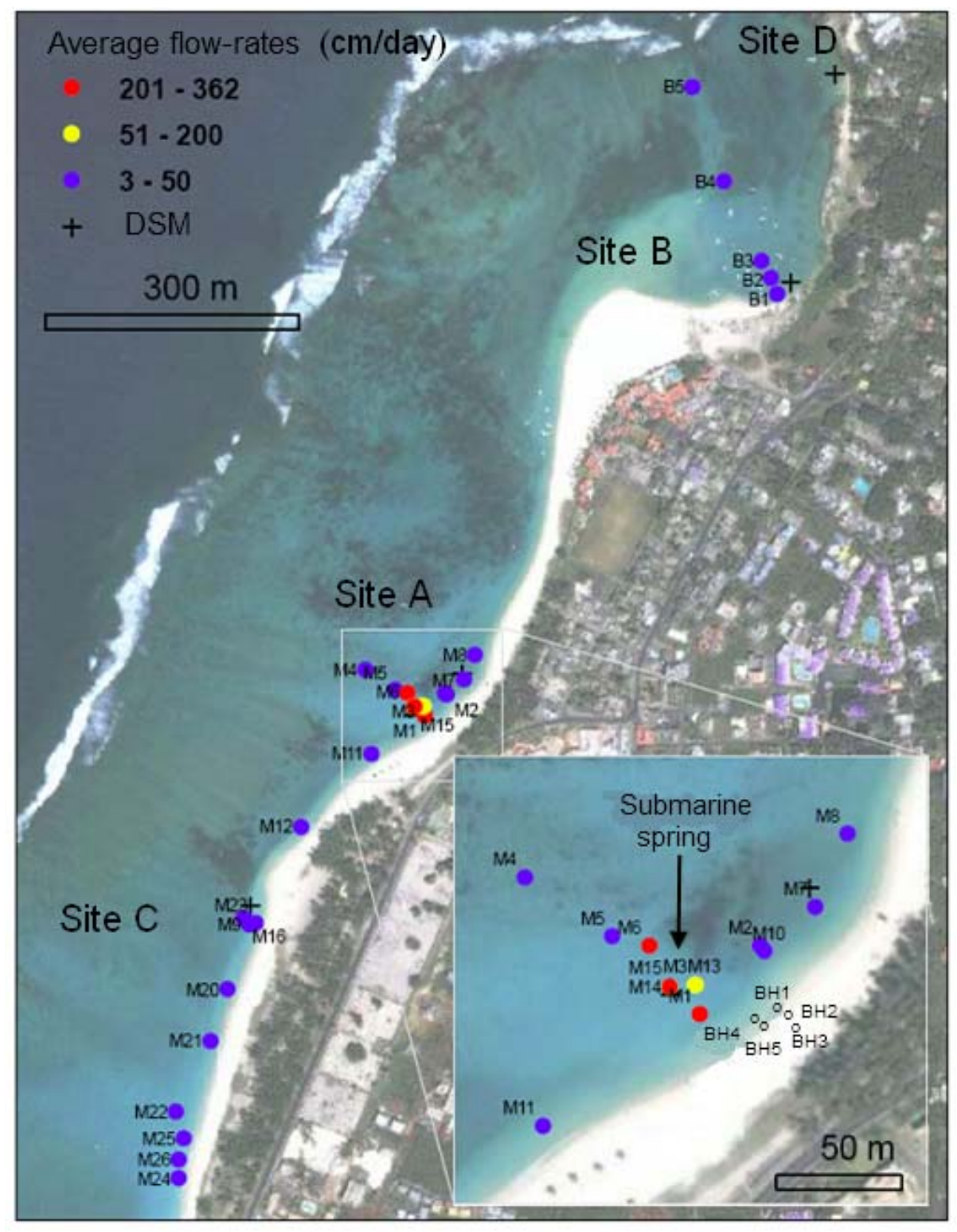

Fig. 2 




Fig. 3



Fig. 4. 
Station 6

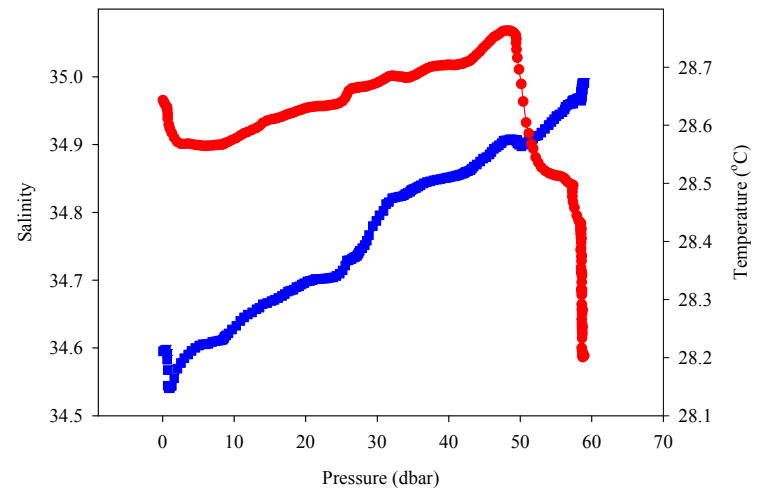

\section{- Salinity}

- Temperature

Station 8

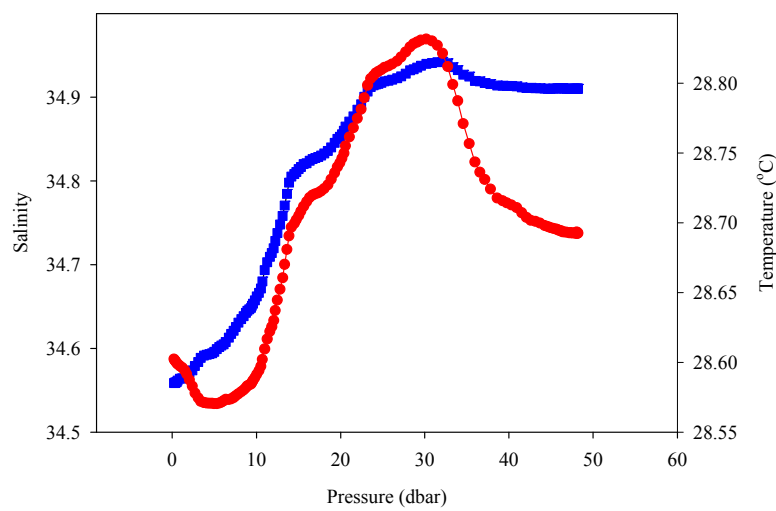

$$
\begin{aligned}
& \longrightarrow \text { Salinity } \\
& \because \text { Temperatur }
\end{aligned}
$$

Station 10



$$
\begin{aligned}
& \longrightarrow \text { Salinity } \\
& \rightarrow \text { Temperature }
\end{aligned}
$$

Fig. 5
Station 7



$$
\begin{aligned}
\qquad \text { Salinity } \\
\rightarrow-\text { Temperature } \\
\text { Station } 9
\end{aligned}
$$



- Salinity

Temperature

Station 11



$\longrightarrow$ Salinity
$\longrightarrow$ Temperature 



Fig. 6



Fig. 7. 



Fig. 8



Fig. 9. 




Fig. 10 
a)

Site B

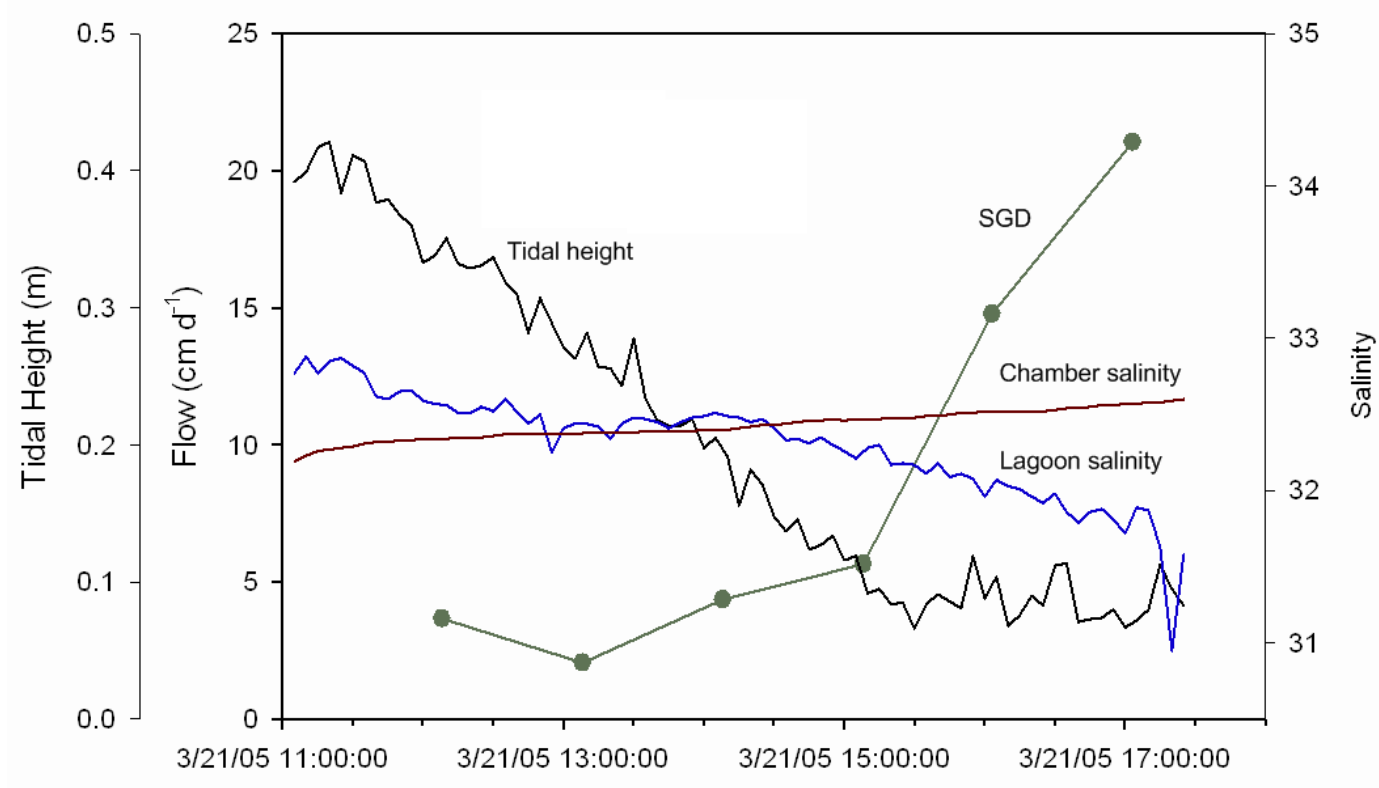

b)

Site A








d) Site D



Fig. 11 




Fig. 12.

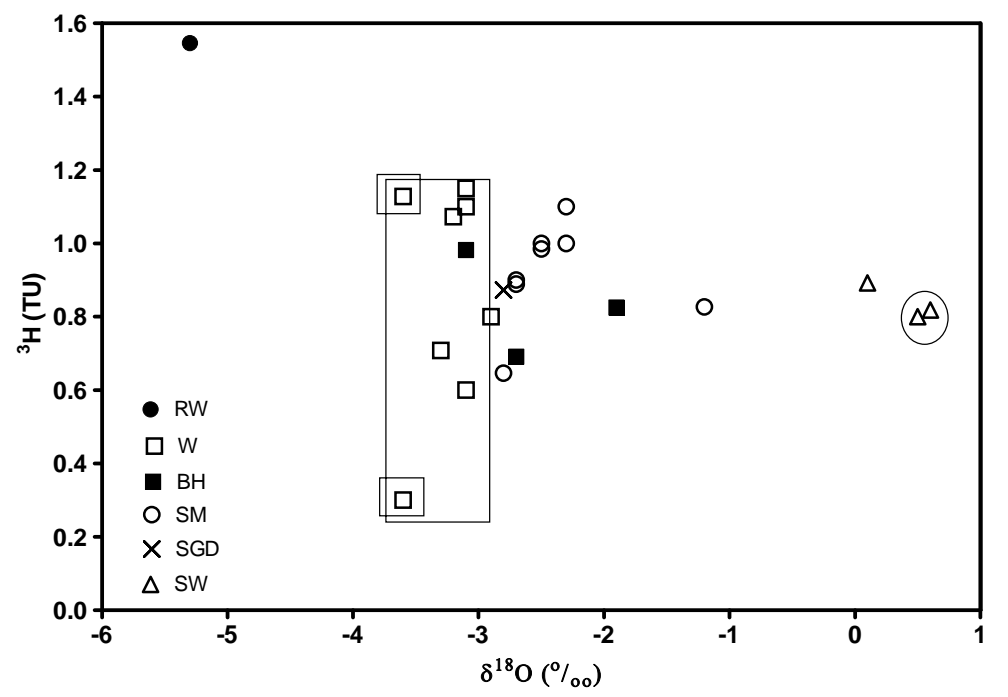

Fig. 13 


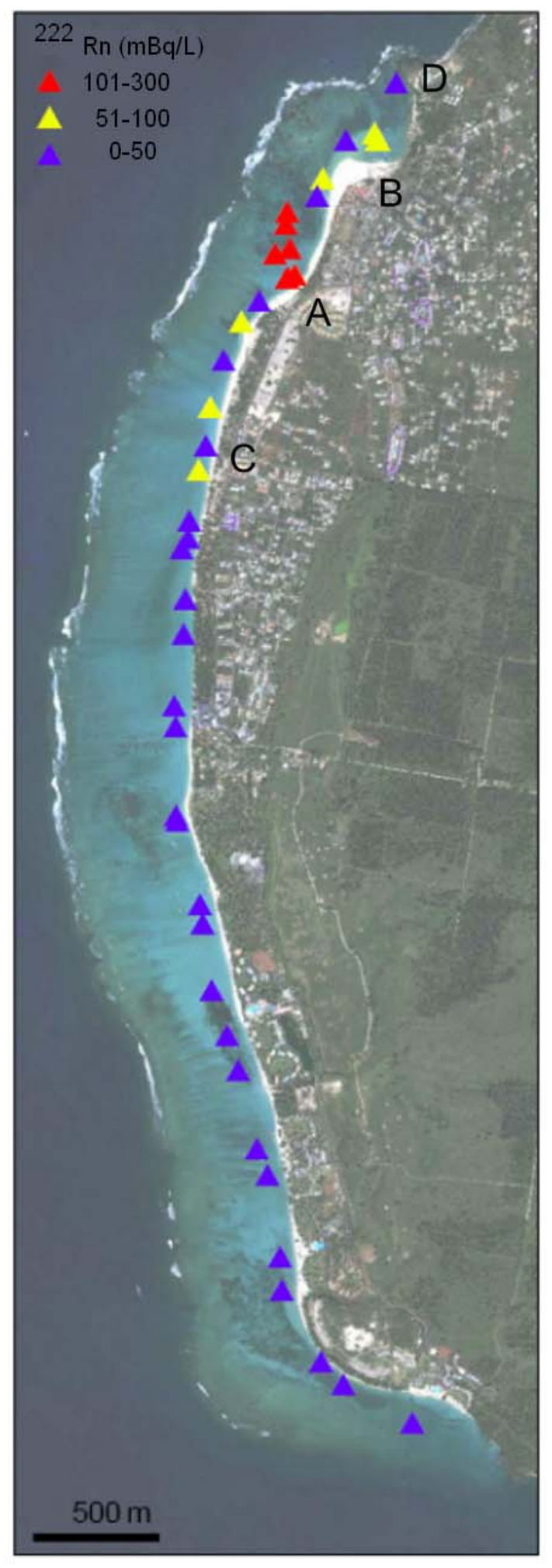

Fig. 14 

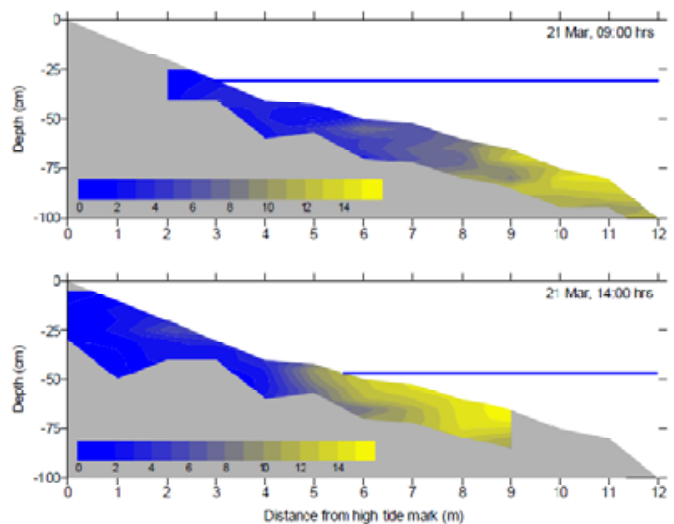

Fig. 15.



Fig. 16 
A.



B.

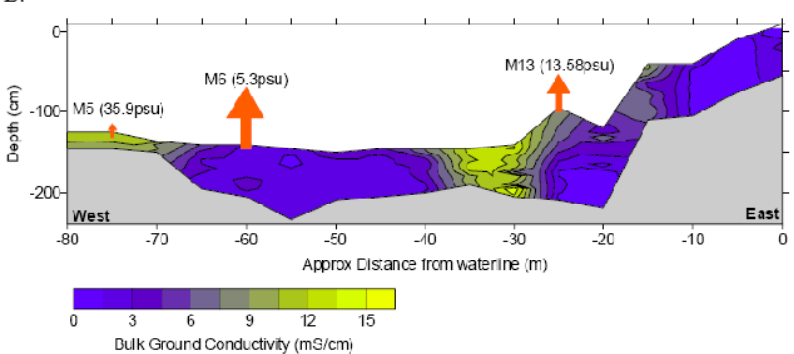

Fig. 17


Fig. 18 

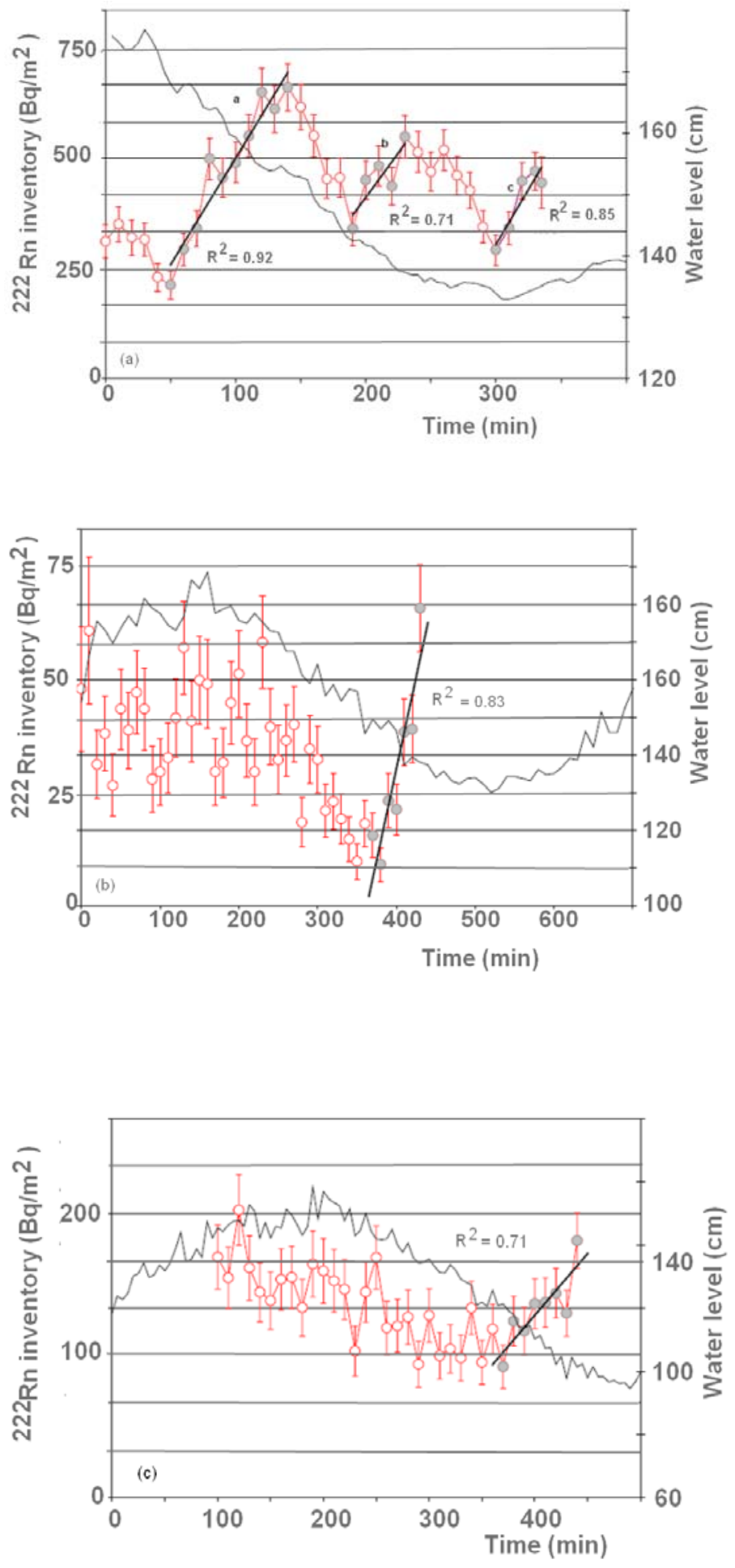

Fig. 19 